\title{
REVISTAMARACANAN
}

Dossiê

\section{De Revert Henry Klumb a Guilherme Antonio dos Santos: 0 Rio de Janeiro em 100 anos de fotografia estereoscópica (1850-1950)}

\section{From Revert Henry Klumb to Guilherme Antonio dos Santos: Rio de Janeiro city in 100 years of stereoscopic photography (1850-1950)}

\author{
Maria Isabela Mendonça dos Santos* \\ Secretaria Municipal de Educação do Rio de \\ Janeiro \\ Rio de Janeiro, Rio de Janeiro, Brasil
}

Recebido em: 28 dez. 2019.

Aprovado em: 10 maio 2020.

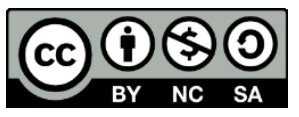

O presente trabalho foi realizado com apoio da Coordenação de Aperfeiçoamento de Pessoal de Nível Superior - Brasil (CAPES) - Código de Financiamento 001.

\footnotetext{
* Professora da Educação Básica na Rede Municipal de Ensino do Rio de Janeiro. Doutora, Mestre e graduada em História pela Universidade Federal Fluminense; Especialista em Preservação e Gestão do Patrimônio Cultural das Ciências e da Saúde pela Casa de Oswaldo Cruz - FIOCRUZ. Pesquisadorabolsista do Programa de Apoio à Pesquisa da Fundação Biblioteca Nacional. (misabelams@gmail.com)

ORCID iD: https://orcid.org/0000-0002-5741-2247

CV Lattes: http://lattes.cnpq.br/8529022982647406
} 


\title{
Resumo
}

Este artigo busca apresentar um panorama da história da estereoscopia e do seu desenvolvimento no Brasil, tomando como fio condutor os fotógrafos profissionais e amadores que se utilizaram da técnica para representar a cidade do Rio de Janeiro desde a década de 1850 até a década de 1950. Inventado no Reino Unido na década de 1830 e distribuído comercialmente a partir da década de 1850, o estereoscópio consistiu numa das formas mais populares de visualização de imagens fotográficas entre a segunda metade do século XIX e a primeira metade do século XX. Entendendo que a técnica tem suas especificidades, buscamos compreender como a estereoscopia atuou na educação do olhar dos observadores brasileiros.

Palavras-chave: Estereoscopia. Fotografia Estereoscópica. Rio de Janeiro.

\begin{abstract}
This paper presents an overview of the history of stereoscopy and its development in Brazil, conducted by the professional and amateur photographers who used the technique to represent the city of Rio de Janeiro from the 1850s until the 1950s. Invented in the United Kingdom in the 1830 s and commercially distributed by the 1850 s, the stereoscope was one of the most popular ways of viewing photographic images between the second half of the nineteenth century and the first half of the twentieth century. Considering the technique in its specificities, we seek to understand how stereoscopy acted in the education of the gaze of Brazilian observers.
\end{abstract}

Keywords: Estereoscopy. Estereoscopic Photography. Rio de Janeiro. 


\section{Introdução}

A estereoscopia consiste em pares de imagens de uma mesma cena que, vistas simultaneamente num visor binocular, o estereoscópio, produzem a ilusão de tridimensionalidade. As vistas estereoscópicas, também conhecidas como "estereografias" ou "estereogramas", podem ser produzidas a partir de diferentes tipos de imagens como desenhos, gravuras ou fotografias, sendo esta última, a forma que ganhou maior popularidade.

O estereoscópio é um dentre os vários aparelhos ópticos surgidos no século XIX que fazem parte do que Jonathan Crary aborda como meios úteis para especificar as transformações no estatuto do observador que, a partir daquele século, serão "pontos de interseção nos quais os discursos filosóficos, científicos e estéticos imbricam-se a técnicas mecânicas, exigências institucionais e forças socioeconômicas". ${ }^{1}$ Para Crary, mais do que objeto material ou parte integrante de uma história da tecnologia, cada um desses instrumentos pode ser entendido pela maneira como está inserido em uma montagem muito maior de acontecimentos e poderes.

Aqui, a intenção maior do autor é traçar algumas condições e forças que definiram ou permitiram a formação de um modelo dominante de observador no século XIX, contrariando explicações que tratam da história da fotografia e do cinema de forma determinista, "no qual uma dinâmica independente de invenção, modificação e aperfeiçoamento mecânicos impõemse em um campo social, transformado-o a partir de fora". ${ }^{2}$ Assim, Crary elege o estereoscópio como a principal tecnologia de produção de efeitos "realistas" na cultura visual de massas que baseou-se em uma reconstrução radical da experiência óptica, sendo mais importante do que a própria fotografia.

Neste artigo, buscaremos analisar como se deu a chegada e a expansão da fotografia estereoscópica no Brasil, tomando como fio condutor a produção desenvolvida na cidade do Rio de Janeiro, entre meados do século XIX e meados do século XX. Nosso objetivo é perceber os usos e funções dados a este tipo de imagem durante o período em questão, bem como analisar como a sede da corte, e posteriormente capital da república, foi representada pelos fotógrafos estereoscopistas profissionais e amadores.

Assim, a proposta deste trabalho encaixa-se no campo intelectual conhecido como "cultura visual" ou "estudos visuais", que segundo W. J. T. Mitchell, trata-se da subdisciplina que foca na visualidade, lincando estética e história da arte com problemas da luz, ótica,

\footnotetext{
1 Além do estereoscópio, temos aparelhos como o taumatrópio, o fenascistoscópio, o zootrópio, o caleidoscópio, o diorama, o panorama e a lanterna mágica. Segundo Crary, esses aparelhos começaram a surgir em meados da década de 1820, a partir do estudo experimental das pós-imagens. Inicialmente, eles tiveram como propósito a observação científica, mas logo se transformaram em formas de entretenimento popular. Todos esses dispositivos se baseavam nas noções de que a percepção não era instantânea e de que havia uma separação entre o olho e o objeto. CRARY, Jonathan. Técnicas do observador. Visão e modernidade no século XIX. Rio de Janeiro: Contraponto, 2012, p. 17.

${ }^{2}$ Idem.
} 
aparatos visuais e experiência, o olho como um órgão de percepção, a direção escópica. Engloba também os estudos das imagens técnicas e científicas, cinema, televisão, mídias digitais, questões filosóficas como a da epistemologia da visão, estudos semióticos das imagens e signos visuais, investigações psicoanalíticas da direção escópica, fenomenologia, fisiologia, estudos cognitivos do processo visual, estudos sociológicos de espectadores e exibição, antropologia visual e muito mais. ${ }^{3}$

Ainda segundo Mitchell, a cultura visual não se limita aos estudos de imagens ou mídias, mas se estende às praticas do cotidiano, do ver e do mostrar e está menos ligada aos significados das imagens e mais às suas vidas e amores. Para o autor, não existe mídia visual. Todas as mídias são misturadas, com vários índices sensórios e tipos de sinais. Ora, se todas as mídias são misturadas, trabalhamos com a perspectiva de que a fotografia estereoscópica possui em seu cerne a busca pelos fenômenos da sinestesia, ou seja, não estimula apenas o campo visual dos observadores, mas todos (ou quase todos) os seus sentidos. Além disso, trata-se de uma técnica imbuída de múltiplas possibilidades sensório-semióticas, localizandose na fronteira entre meio artístico e documental.

A questão central deste trabalho consiste em esclarecer se o Brasil participou da modernização do olhar identificada por Jonathan Crary, ou se manteve à margem deste processo. O país também teve no estereoscópio a principal tecnologia de produção de efeitos "realistas", como defende o teórico, ou este posto foi tomado exclusivamente pela fotografia bidimensional?

Nossa proposta considera as estereoscopias como imagem/documento, imagem/monumento que informa, mas também conforma visões de mundo. ${ }^{4}$ Aqui a fotografia é tomada como fonte e objeto da história. Ela é uma prática social e experiência histórica, duas noções cujo encontro está apoiado nas formas simbólicas da cultura e nas produções materiais dos sujeitos fotógrafos, dos observadores das fotografias e das instituições que as agenciam/arquivam. ${ }^{5}$

Nesse sentido, a fim de responder as questões colocadas, trabalhamos com a análise de coleções de fotografias presentes em diversas instituições brasileiras, públicas e privadas. Destacam-se, entre elas, a Coleção Thereza Christina Maria, da Biblioteca Nacional - onde encontra-se a maior parte das fotografias produzidas pelo fotógrafo Revert Henry Klumb -, a Coleção Fotografias Avulsas do Arquivo Nacional e as coleções Guilherme Santos do Museu da Imagem e do Som e do Instituto Moreira Salles. Dentre as fontes verbais, destacamos reportagens e matérias de periódicos como o Boletim de Belas Artes e a Revista A Noite - para análise da atuação do fotógrafo Guilherme Santos.

\footnotetext{
${ }^{3}$ MITCHELL, Willian J. T. What do pictures want? Chicago: The University of Chicago Press, 2005 , p. 339. 4 LE GOFF, Jacques. Documento/Monumento. Enciclopedia Einaudi. No. 1. Lisboa: Imprensa Nacional Casa da Moeda, 1985.

5 MAUAD, Ana; LOPES, Marcos. História e Fotografia. In: CARDOSO, Ciro F.; VAINFAS, Ronaldo (orgs.). Domínios da História. Rio de Janeiro: Elsevier, 2012, p. 271.
} 


\section{O século XIX e o surgimento da fotografia estereoscópica}

O primeiro estereoscópio foi inventado em 1833, escocês Mr. Charles Wheatstone (1802-1875). Porém, foi o inglês David Brewster (1781-1868), que na década de 1850 aperfeiçoou o aparelho combinando-o com a daguerreotipia (Figura 1). Após ser apresentada à Rainha Vitória na Exposição Internacional de Londres em 1851, a estereoscopia caiu no gosto do público e tornou-se, segundo J. Crary, "o mais importante modo de lidar com imagens produzidas fotograficamente". ${ }^{6}$

Figura 1 - Daguerreótipo estereoscópico Mascher, 1853.

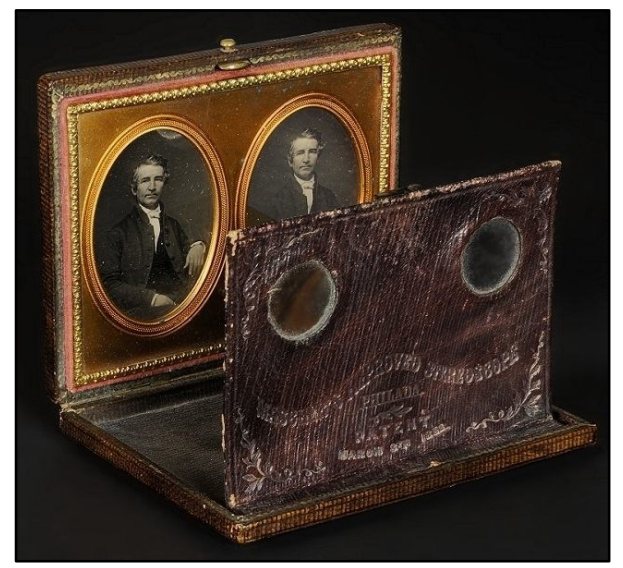

Fonte: Mascher Stereo Daguerreotype Viewer with Original Image Pair, c.1853. [s.d.]. Collectors Weekly. (Site). Disponível em: https://www.collectorsweekly.com/stories/178056-mascher-stereo-daguerreotypeviewer-with. Acesso em: nov. 2019.

A fotografia estereoscópica deu grande impulso às expedições fotográficas e aos trabalhos de documentação. O enorme consumo de vistas, alimentava os desejos dos observadores por paisagens longínquas, cenas urbanas e construções famosas. ${ }^{7}$ Além dessas temáticas, a pornografia foi um dos grandes temas da fotografia estereoscópica. Alguns autores consideram a fotografia estéreo o primeiro sistema visual universal de comunicação, antes do cinema e da televisão, podendo ser vista como o natural e direto antepassado do cinema de atrações. ${ }^{8}$

Em termos gerais, podemos dizer que a capilarização da fotografia estereoscópica se dá a partir das elites em direção às bases da pirâmide social. A sala de visitas da família burguesa é o lugar por excelência do consumo desta volumosa produção. "Colecionadas em grupos e séries jaziam, ao lado do álbum de família, disponíveis como objetos de uso nos rituais das

\footnotetext{
${ }^{6}$ CRARY, Jonathan. Técnicas do observador. Op. cit., p. 116.

7 Cf.: TURAZZI, Maria Inez. Poses e Trejeitos: a fotografia e as exposições na era do espetáculo. Rio de Janeiro: Funarte; Rocco, 1995.

8 TRACHTENBERG, Alan. Reading American photographs: Images as history - Mathew Brady to Walker Evans. Hill and Wang: NovaYork, 1989, p. 17; GUREVICH, Leon. The stereoscopic attraction: Threedimensional imaging and the spectacular paradigm 1850-2013. Convergence: The International Journal of Research into New Media Technologies, v. 19, n. 4, p. 396-405, 2013, p. 399.
} 
trocas sociais apropriadas a este aposento". ${ }^{9}$

Na última década do século XIX, o uso industrial da gelatina com brometo de prata permitiu a comercialização de filmes mais sensíveis e práticos a baixo custo. Essa transição marca a emergência das corporações norte-americanas, e o relativo declínio dos mercados europeus que já davam sinais de desgaste desde os anos 1870. Nos Estados Unidos, a estereoscopia teve um desenvolvimento industrial e comercial impressionante e quantitativamente muito maior que na Europa. Encontrando uma economia próspera e um desenvolvimento industrial sedento de novidades, teve uma grande aceitação, especialmente entre colecionadores e associações. Quase todas as cidades americanas foram estereografadas. A América e seu povo, os grandes parques, o Grand Canyon, os negros, os índios e a guerra civil, apareciam como os grandes temas da estereoscopia estadunidense. ${ }^{10}$ Rodrigo Peixoto considera esse momento o auge da fotografia estereoscópica como entretenimento, que se caracteriza pela venda de cartões avulsos, pequenos conjuntos narrativos e turísticos, ou de teor erótico. ${ }^{11}$

Figura 2 - Veneza, Verascope Richard, S./d.

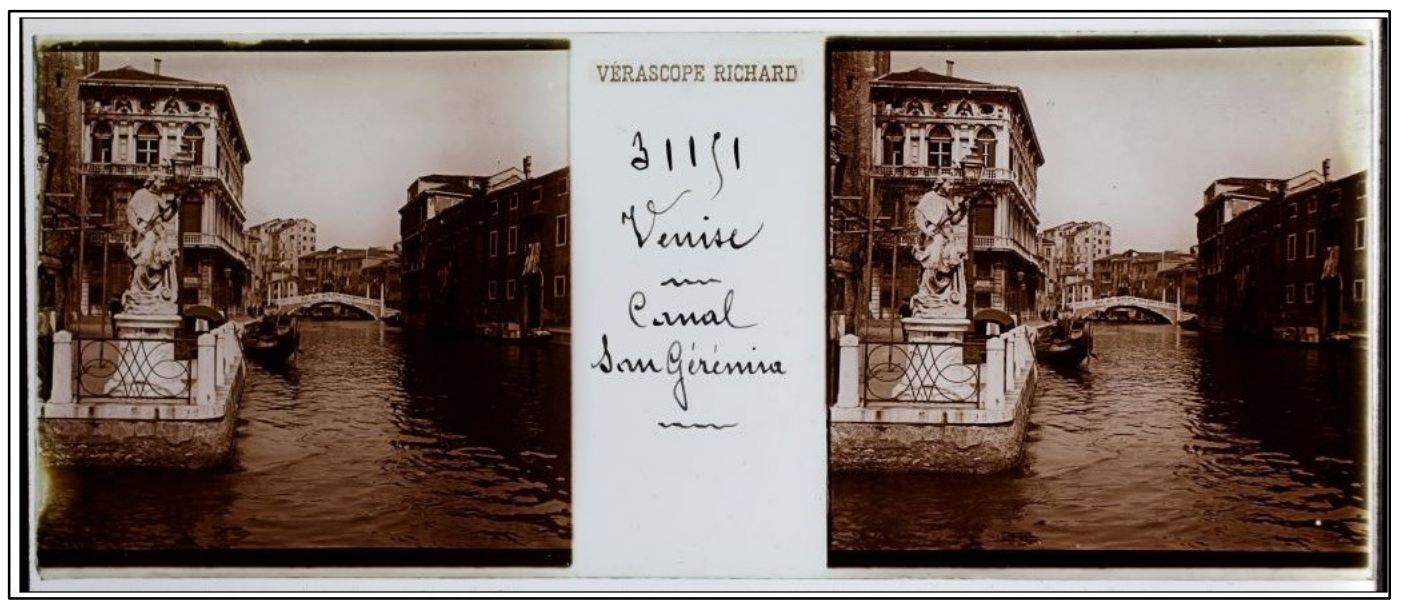

Fonte: INSTITUTO Moreira Sales - Rio de Janeiro. Coleção Guilherme Santos. Veneza, Verascope Richard. [s./d.].

9 ADAMS, Gavin. A mirada estereoscópica e a sua expressão no Brasil. 2004. Tese (Doutorado em Comunicação e Estética do Audiovisual) - Escola de Comunicações e Artes da Universidade de São Paulo, São Paulo, p. 7.

${ }^{10}$ PARENTE, José Inácio. A estereoscopia no Brasil. Rio de Janeiro: Sextante, 1999, p. 15.

11 PEIXOTO, Rodrigo. Uma certa imagem de um mundo: Estereoscopia e educação visual no início do século XX; uma investigação a partir da coleção Pestalozzi (MIMO). RCL - Revista de Comunicação e Linguagens, Lisboa, n. 47, p. 34-52, 2017.

Adams destaca como os principais temas da fotografia estereoscópica: A estereoscopia pedagógica, utilizada como ferramenta educacional em escolas, mas também para utilização particular das famílias abastadas, com imagens de diversas áreas do conhecimento como geografia, biologia, etc.; a estereoscopia turística, com imagens das mais variadas paisagens e monumentos do globo, muitas vezes confundia-se com as estereoscopias pedagógicas e possibilitavam uma viagem sem sair do lugar, o chamado "turismo de sofá"; e a estereoscopia erótica, reservada aos chefes de família, ou homens solteiros, para observação solitária, essas imagens eram, muitas vezes vendidas clandestinamente. ADAMS, Gavin. A mirada estereoscópica... Op. cit., p. 7. 
Entre a segunda metade do século XIX e primeira metade do século $X X$, a fotografia estereoscópica teve momentos de maior e menor produção e consumo. Ao longo deste período, este tipo de fotografia, no entanto, não se restringiu às temáticas que acabamos de elencar. Se tudo é digno de ser fotografado, tanto as fotoestereoscopias das empresas especializadas quanto as dos fotógrafos amadores deparou-se com um universo quase ilimitado de temáticas possíveis, sendo o limite dado apenas pela possibilidade da câmera estereoscópica chegar ou não em determinado lugar.

\section{A fotografia estereoscópica no Brasil: o pioneirismo de R.H. Klumb}

O Brasil não ficaria de fora do processo de modernização do olhar ao qual se refere $\mathrm{J}$. Crary. Ainda que até a última década do século XIX a produção de fotografias estereoscópicas no país tenha sido muito tímida quando comparada com a europeia ou a estadunidense, desde a década 1850 os grandes mestres da fotografia brasileira já produziam estereoscopias. ${ }^{12}$

O alemão Revert Henrique Klumb (1826-1886), foi o fotógrafo pioneiro da técnica tridimensional no país. Efetuando uma ampla documentação com esse sistema entre os anos de 1855 e 1862, realizou cerca de 200 imagens estereoscópicas mostrando a capital do império ainda com feições coloniais. ${ }^{13}$ Fotógrafo da corte até 1880 , em seu trabalho Klumb focaliza os principais monumentos e logradouros públicos da época, sendo o primeiro a se aventurar pelo Alto da Boa Vista e pela Floresta da Tijuca. Seu trabalho possui valor excepcional, pelo pioneirismo técnico e pela documentação histórica da cidade e do estado do Rio de Janeiro, de cidades do estado de Minas Gerais, além dos registros da família imperial brasileira. ${ }^{14} \mathrm{Em}$ 1860, Klumb é condecorado com uma menção honrosa na 14a Exposição Geral de Belas Artes da Academia Imperial de Belas Artes e, em 1872 publicou um dos primeiros livros de fotografia editados no Brasil: Doze Horas em Diligência. Guia do Viajante de Petrópolis a Juiz de Fora, com textos e fotos de sua autoria. ${ }^{15}$ Viveu no Rio de Janeiro de 1855 até o final da década de 1850, produzindo belas fotografias estereoscópicas sobre a cidade, suas paisagens e seus habitantes e registrando os usos e os costumes da época, inclusive o regime de escravidão. É importante destacar que no oitocentos, era a estética do exótico que delineava a escravidão. "As classes populares só figuravam nas fotografias na condição de "tipos humanos", objetos de atenção das casas fotográficas para produzir o lado pitoresco da

\footnotetext{
12 SANTOS, Ma. Isabela M. dos. A mirada estereoscópica de Guilherme Santos: Cultura Visual na cidade do Rio de Janeiro Séculos XIX e XX. 2019. Tese (Doutorado em História) - Instituto de História da Universidade Federal Fluminense, Niterói (RJ), p. 69.

13 Revert Henrique Klumb. (Verbete). In: Enciclopédia Itaú Cultural de Arte e Cultura Brasileiras. São Paulo: Itaú Cultural, 2020. Disponível em: http://enciclopedia.itaucultural.org.br/pessoa21647/reverthenrique-klumb. Acesso em: 05 jan. 2018.

14 BIBLIOTECA Nacional - Rio de Janeiro. Coleção Thereza Christina Maria, KLUMB Revert Henrique, 1855-1880. fl. 1-76.

${ }^{15}$ George Leuzinger. (Verbete). In: Enciclopédia Itaú Cultural de Arte e Cultura Brasileiras. São Paulo: Itaú Cultural, 2020. Disponível em: http://enciclopedia.itaucultural.org.br/pessoa21629/georgeleuzinger. Acesso em: 05 jan. 2018.
} 
sociedade imperial". ${ }^{16}$

George Leuzinger (1813-1892) foi outro importante pioneiro da fotografia estereoscópica no Brasil. Em 1861, o suíço abriu uma loja na Rua do Ouvidor equipando-a "com os melhores instrumentos ingleses para fotografar paisagens, panoramas e vistas estereoscópicas". ${ }^{17}$ Assim, durante quase dez anos, foram editados pela Casa Leuzinger, diversos álbuns com vistas do Rio de Janeiro, Niterói, Petrópolis e Teresópolis. ${ }^{18}$ No Segundo Reinado, a Casa Leuzinger destacou-se como divulgadora das paisagens do país, em gravura e fotografia e, em 1867, foi premiada com uma menção honrosa na Exposição Universal de Paris pelos panoramas do Rio de Janeiro e pelas fotografias de A. Frisch de índios da Amazônia. ${ }^{19}$ Com Auguste Stahl (1826-1877) e Hunnewell (1844-1821), Leuzinger ilustra, em 1866, o livro Viagem ao Brasil, 1865-1866, de Louis Agassiz e Elizabeth Cary Agassiz.

Também Marc Ferrez (1843-1923) teria se utilizado da técnica tridimensional em trabalhos que constituem até os dias de hoje os acervos da Biblioteca Nacional, do Arquivo Nacional, do Instituto Moreira Salles e do J. Getty Museum. Neste último acervo encontram-se as estereoscopias produzidas por Ferrez para a Comissão Geológica do Império, realizada pelo geólogo inglês Charles Frederick Hartt (1840-1878) entre 1875 e 1878. Já no Instituto Moreira Salles, encontram-se as estereoscopias coloridas que Ferrez produziu a partir de 1912, como as placas autocromos Lumiére, primeiro processo industrializado para a produção deste tipo de fotografia. ${ }^{20}$

Figura 3 - Passeio Público, por Marc Ferrez, [1860-1890].

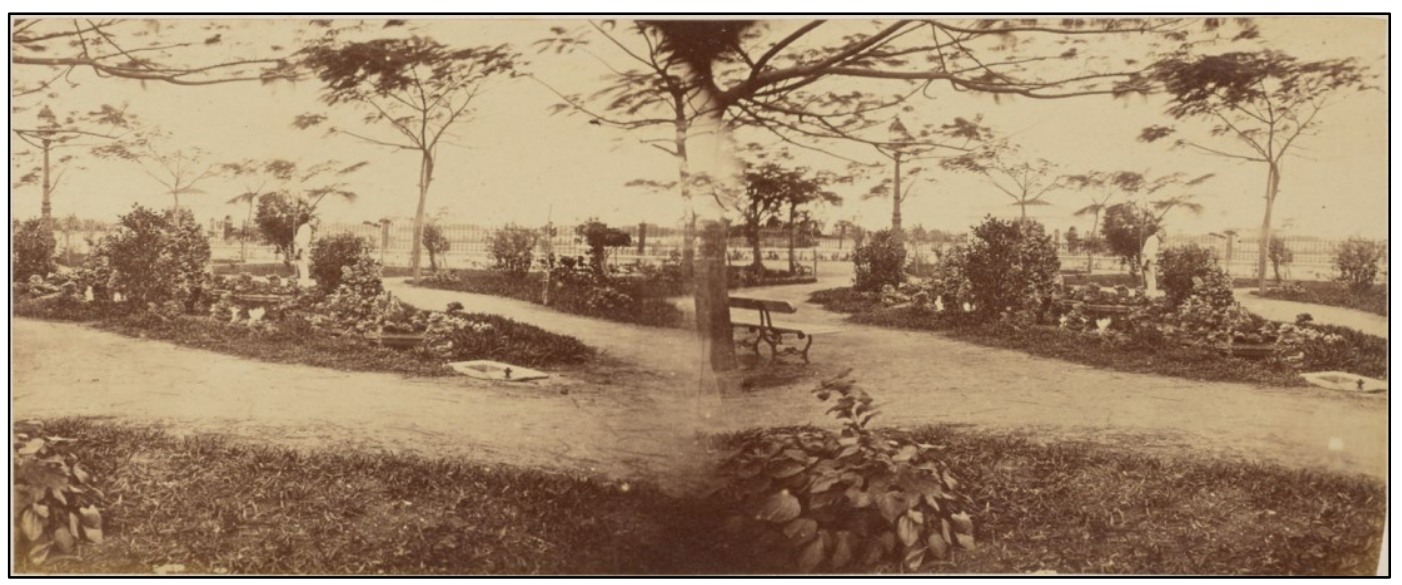

Fonte: BIBLIOTECA Nacional - Rio de Janeiro. FERREZ, Marc. Passeio Público. [1860-1890].

\footnotetext{
${ }^{16}$ MAUAD, Ana. Imagem e autoimagem do Segundo Reinado. In: NOVAIS, Fernando A. (coord.). História da vida privada no Brasil. Vol. 2: Império: a corte e a modernidade nacional. Org.: Luiz Felipe de Alencastro. São Paulo: Companhia das Letras, 1997, p. 205.

17 PESSANHA. Maria Edith de Araújo. A Estereoscopia: O Mundo em Terceira Dimensão. Rio de Janeiro: M. E. A. Pessanha, 1991, p. 18.

${ }^{18}$ As imagens de George Leuzinger constituem o acervo iconográfico da Biblioteca Nacional e podem ser consultadas em: Biblioteca Nacional Digital. (Portal Eletrônico). Colleção D. Thereza Christina, George Leuzinger, Rio de Janeiro entre 1865 e 1874. Disponível em: http://bndigital.bn.br/terezacristina/page3.htm. Acesso em: jan. 2018.

19 TURAZZI, Maria Inez. Poses e Trejeitos... Op. cit., p. 251.

20 No primeiro dia da primavera, as cores de Marc Ferrez (1843-1923). Brasiliana Fotográfica. (Portal Eletrônico). Disponível em: http://brasilianafotografica.bn.br/?p=9714. Acesso em: 30 abr. 2020.
} 
Além de Klumb, Leuzinger e Ferrez, Boris Kossoy cita como fotógrafos que produziam estereoscopias na cidade do Rio de Janeiro, os húngaros Biranyi \& Kornis, estabelecidos na década de 1850, Lamartres, no ano de 1858, e Affonso Ruelle, na década de 1860. Além destes, encontramos registros de estereoscopias da dupla de fotógrafos Carneiro \& Smith, que atuou no Rio de Janeiro entre as décadas de 1850 e $1880 .^{21}$

Voltando ao pioneiro R. H. Klumb, na "Coleção D. Thereza Christina Maria" da Biblioteca Nacional, encontra-se a maior parte da produção estereoscópica do fotógrafo, num total de 265 estereogramas. Há ainda 15 estereogramas de Klumb no acervo do Museu Imperial: 14 na Coleção Lourenço Luiz Lacombe e 1 com carimbo da Coleção D. Thereza Christina Maria. Já no Instituo Moreira Salles, foram encontrados um total de 11 estereoscopias: 2 na Coleção Gilberto Ferrez; 7 na Coleção Mestres do século XIX. Estima-se que suas estereoscopias mais antigas foram produzidas entre 1855-56. A maior parte das estereoscopias presentes nesta coleção, contudo, é de 1860 (202 estereoscopias). Datadas entre 1861 e 1865, foram encontradas 28 estereoscopias: 2 de 1869 e 4 da década de 1860, porém sem data definida; 1 de 1880 e 20 sem data definida. ${ }^{22}$

Ao analisar as estereoscopias de Klumb na tese $A$ presença dos aparelhos e dispositivos ópticos no Rio de Janeiro do século XIX, Maria Christina Miranda da Silva conclui que o conjunto de sua obra insere-se numa demanda social de imagens típica do panorama cultural do século XIX.

Um inventário da cidade do Rio de Janeiro composto por suas igrejas, edifícios públicos, monumentos, ruas, morros, vistas de vários ângulos da cidade tomadas de cima dos morros e de torres de igrejas, retratos do império, assim como da vegetação característica do país. Uma cidade em desenvolvimento, com seus costumes e gentes cercados por uma natureza exuberante. ${ }^{23}$

Segundo Schwarcz, durante o segundo reinado, era na sede do império que se sentiam mais de perto os resultados do final do tráfico negreiro, cujo capital passava a ser investido também em novas edificações e nas distintas lojas da corte. Toda a urbanização da cidade vivia uma verdadeira revolução. Tomando a Paris burguesa e neoclássica como modelo, foram realizadas na cidade do Rio de Janeiro diversas melhorias, especialmente a partir da década de 1850. Calçamento com paralelepípedo, iluminação a gás, rede de esgoto, abastecimento domiciliar de água, e bonde puxados a burro. O mundo dos passeios e dos novos hábitos de consumo também se alterava rapidamente. Assim nascia a rua do Ouvidor, onde se encontravam as mais luxuosas casas de chá, lojas de moda, joalherias, floristas, além dos principais jornais da cidade. "A cidade fluminense, sede da corte, passará a funcionar como um polo centralizador e difusor de hábitos, costumes e até linguagens para todo o país, além de se

${ }^{21}$ KOSSOY, Boris. Origens e expansão... Op. cit.; SILVA, Maria Cristina Miranda da. A presença dos aparelhos e dispositivos ópticos no Rio de Janeiro do século XIX. 2006. Tese (Doutorado em Comunicação) - Pontifícia Universidade Católica de São Paulo, São Paulo, p. 85.

${ }^{22}$ Idem.

23 Ibidem, p. 90. 
transformar no cenário principal em que se desenrolava a dramatização da vida social da boa sociedade". ${ }^{24}$

Na produção de Klumb destacam-se aspectos interessantes da sede da corte imperial em transformação. Panorâmicos da Floresta da Tijuca, do Morro do Castelo, da Praça XV, dos bairros da Glória, da Lapa, da Rua do Ouvidor, entre outras vias comerciais e residenciais do centro da cidade, foram, assim, contempladas pelo fotógrafo. Do mesmo modo, não foram esquecidos os detalhes de cada um destes logradouros já citados, como por exemplo, a famosa, fonte do Mestre Valentim no Largo do Paço. Aspectos ainda bastante rurais do Rio de Janeiro imperial também fazem parte dos registros de Klumb presentes no acervo da BN. Assim, no Alto da Boa Vista ele registrou fazendas e sítios, além do trabalho realizados pelos escravos locais. Do mesmo modo, são feitos registros de diversas fazendas do interior da província.

As fotografias de paisagem produzidas por Klumb inserem-se nas novas exigências colocadas pela visualidade moderna, seguida pelos demais fotógrafos daquele período. Sem desconsiderar os códigos de representação da pintura, Klumb apoiava-se na exatidão da forma e na fidelidade do registro, colaborando para a instituição de uma nova maneira de olhar para a natureza, indo ao encontro de um movimento que vai tirar o observador do papel de contemplador passivo e colocá-lo como interventor da cena. De acordo com Turazzi, este novo olhar envolve uma mudança de perspectiva em relação à história.

No Brasil, o esquadrinhamento do território pela fotografia, assim como pela geografia, geologia ou botânica, além de ser matéria de interesse científico, é também uma necessidade política de consolidação do Estado imperial: vistas e panoramas fotográficos são reconhecidos como enquadramentos do país que tipificam cenários, costumes e gentes da terra, elegendo-os como atributos singulares de uma identidade nacional em construção, consubstanciada na variedade e exuberância dessas imagens. ${ }^{25}$

Ainda sobre a produção de Klumb, não podemos deixar de citar a fartamente documentada família imperial. Durante o Segundo Reinado, um dos grandes entusiastas da fotografia no Brasil será o próprio imperador. Primeiro brasileiro a adquirir e utilizar um equipamento de daguerreotipia em 1840, Dom Pedro II tornou-se a figura central da fotografia brasileira do século XIX, de modo a constituir a primeira grande coleção de fotografias do país e rivalizar com a rainha Vitória da Inglaterra na atribuição de honrarias aos praticantes da nova técnica. ${ }^{26}$ Homem culto e atento às manifestações artísticas, descobertas científicas e avanços tecnológicos, o imperador esteve à frente de um projeto civilizatório para o país que tinha no binômio Civilização e Natureza, os componentes da formulação ideológica da nação.

A expansão da fotografia, por sua vez, fez parte de um amplo processo de intercâmbio com as nações europeias. D. Pedro II esteve atento a este aspecto quando investiu na produção e divulgação de imagens sobre o Brasil. Diante da visível expansão dos negócios

${ }^{24}$ SCHWARCZ, Lilia Moritz. As Barbas do Imperador: D. Pedro II, um monarca nos Trópicos. São Paulo: Companhia das Letras, 1998.

25 TURAZZI, Maria Inez. Marc Ferrez: Fotografias de um "artista ilustrado". São Paulo: Cosac \& Naify, 2000, p. 14.

${ }^{26}$ VASQUEZ, Pedro Karp. A fotografia no Império. Rio de Janeiro: Zahar, 2002, p. 8. 
ligados ao setor, o governo imperial apressa-se em regulamentar a atividade, a fim de extrair impostos desse novo ramo industrial e comercial. Um investimento de peso foi feito também no âmbito das exposições internacionais. Configurando-se como encarnação do progresso, no recinto das exposições "a internacionalidade do espetáculo materializava a expansão do horizonte capitalista". ${ }^{27}$ Nestes espaços, as nações participantes podiam se inserir numa espécie de hierarquia do progresso e aí a fotografia encontraria uma função incontestável. Pois, mais do que qualquer outra mídia, era capaz de concentrar representações supostamente objetivas dos mais longínquos e estranhos lugares do mundo.

A história do desenvolvimento da fotografia no Brasil relaciona-se, então com a história das exposições nacionais e internacionais do país. Inseridas num processo mais amplo de construção e afirmação de uma "identidade brasileira", essas duas histórias estão ligadas a um tipo de leitura da "história nacional", tipicamente oitocentista que objetivava reproduzir fielmente o presente e elaborava as imagens de seu futuro. No Brasil, era grande a empolgação do imperador com as exposições e, por esta razão, em 1861, D. Pedro II abre a primeira Exposição Nacional do País.

Precedidas por exposições provinciais, as primeiras exposições nacionais representaram um estímulo à expansão da atividade fotográfica no país, ao mesmo tempo que passaram a levar para o exterior, sob a chancela do governo imperial, retratos e paisagens do Brasil que, pouco a pouco, divulgariam no meio fotográfico internacional nomes como o de Leuzinger, Pacheco, Ferrez e outros. $^{28}$

Enquanto amante da fotografia, o imperador acompanhou de perto os progressos da técnica e os trabalhos dos profissionais que atuavam no Brasil. O título de "fotógrafo da Casa Imperial" conferia aos fotógrafos agraciados, sobretudo prestígio e popularidade, mais do que honraria e distinção. Além de proporcionar um aumento significativo da clientela desses profissionais, incluía na lista de cliente dos mesmos, a própria família imperial. Não obstante, nenhuma outra família gastou tanto com fotografia quanto a imperial. ${ }^{29}$

As fotografias pertencentes à família imperial incluem uma gama variada de temas: desde os retratos posado mais formais, passando pelas imagens do cotidiano, até os panoramas e os registros das solenidades do Império em diferentes províncias. Existiam ainda as fotografias que eram enviadas às exposições universais, onde a imagem do Brasil adequava-se a cultura ocidental. Numa dessas fotos, o imperador é retratado acompanhado por livros, pelo globo e por canetas-tinteiros, todos signos condizentes com um Brasil moderno e culto. O imperador é a imagem do Império nas exposições universais, e a fotografia possibilita essa identificação. ${ }^{30}$

O interesse do imperador pela fotografia denota, nesse sentido, mais do que o objetivo de promover uma imagem do Brasil enquanto nação inserida no processo civilizatório, a promoção da auto-imagem do monarca enquanto símbolo desta "linguagem civilizatória". Assim, a imagem de D. Pedro "amante das letras e das artes" difundida pelos fotógrafos reais,

27 TURAZZI, Maria Inez. Poses e Trejeitos... Op. cit., p. 28.

28 Ibidem, p. 105.

${ }^{29}$ Cf.: MAUAD, Ana. Imagem e autoimagem... Op. cit.

30 Ibidem, p. 197. 
foi igualmente importante para o processo de construção da nacionalidade brasileira. Conforme Mauad, "enquanto a imagem da corte era uma imagem não somente pública, mas publicada nos jornais e nas exposições universais, a imagem do Império ainda tinha como modelo a família imperial". ${ }^{31}$

Por esta razão, a família imperial será amplamente fotografada pelos mais consagrados fotógrafos e das mais diferentes formas. Em fotopinturas, fotomontagens, em estúdios simulando ambientes naturais, situações solenes ou informais e, como não poderia deixar de ser, em retratos estereoscópicos. Introduzida no país na segunda metade do século XIX, a estereosocopia terá como um dos seus grandes incentivadores, mais uma vez, o imperador D. Pedro II.

Um dos fotógrafos preferidos da família imperial, tendo sido professor de fotografia da princesa Isabel, podemos concluir que as estereoscopias de Klumb ajudaram na construção da imagem de um "Brasil Moderno", recriando seus espaços urbanos e, sobretudo, inserindo o observador numa modernidade construída pelo olhar. ${ }^{32}$ É o que podemos observar em algumas vistas panorâmicas da cidade do Rio de Janeiro e de Petrópolis tomadas pelo fotógrafo, que revelam uma cidade urbanizada e repleta de construções e melhoramentos.

Figura 4 - Passeio Público, por R.H. Klumb, 1862.

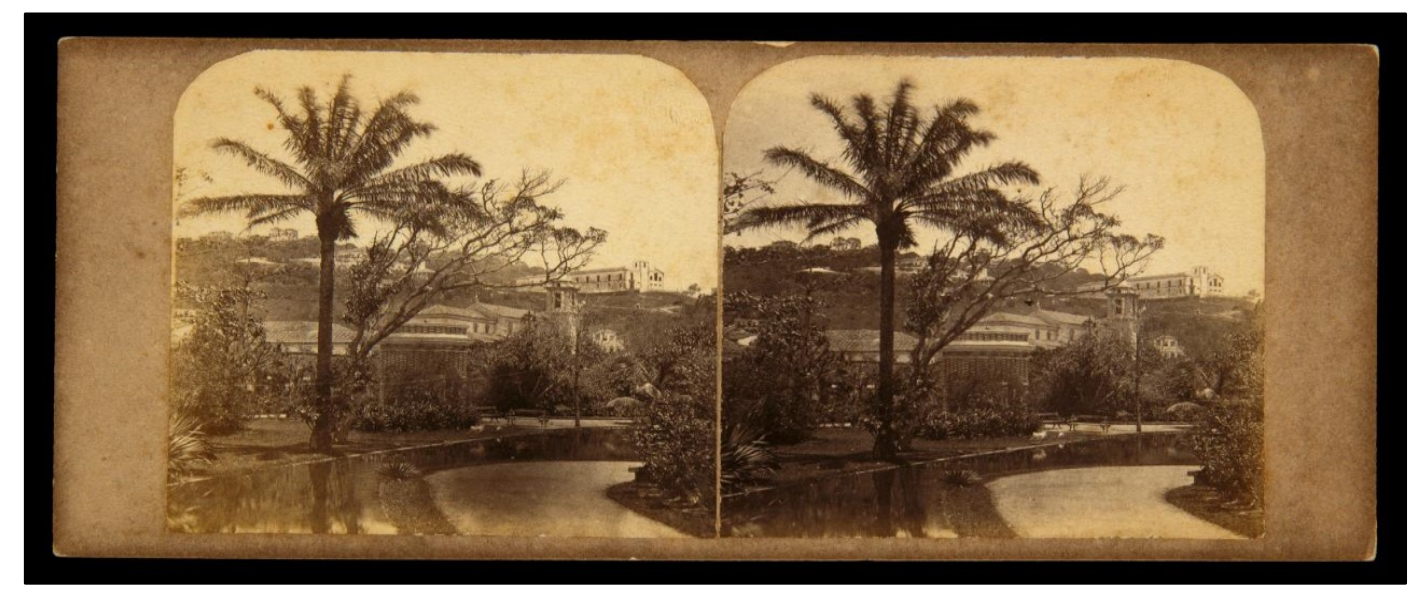

Fonte: BIBLIOTECA Nacional - Rio de Janeiro. KLUMB, R. H. Passeio Público. 1862.

\section{Década de 1890: os cartões estereoscópicos brasileiros}

Na última década do século XIX, a produção estereoscópica dá um salto no mundo inteiro. No Brasil, empresas europeias como a Richard Verascope e estadunidenses como a Keystone View e a H.C.Whitte - fundadas respectivamente em 1892 e $1899^{33}$ - começam a enviar fotógrafos que vão registrar em cartões estereoscópicos, paisagens e aspectos exóticos do país. Portanto, podemos dizer que a partir da década de 1890, o Brasil começa a se inserir

\footnotetext{
${ }^{31}$ MAUAD, Ana. Imagem e autoimagem... Op. cit., p. 185.

32 SILVA, Maria Cristina Miranda da. A presença dos aparelhos... Op. cit., p. 92.

33 DARRAH, William C. The World of Stereographs. Nashville: Land Yatch Press, 1997, p. 51-52.
} 
oficialmente como paisagem de "turismo estereoscópico". ${ }^{34}$

Nesse período, que coincide com os primeiros anos do regime republicano no país, temos o surgimento de uma produção seriada de cartões estereoscópicos brasileiros. A primeira iniciativa é de um empresário filantropo e amante das artes, José Francisco Correia, o Conde de Agrolongo (1853-1829). Proprietário da Fábrica de Fumos Marca Veado, a mais importante empresa do gênero no século passado, Correia foi um dos pioneiros da fotografia amadora no país. Ele iniciou a campanha publicitária de sua marca distribuindo figurinhas estereoscópicas como brindes colocados nos maços de cigarros. Segundo Parente, esses cartões estereoscópicos viraram uma grande moda, "associando o interesse de conhecer grandes cidades e monumentos, costumes e povos ao prazer de colecionar, típico da época".35

Figura 5 - Rua Uruguaiana, Marca Veado, [1890-1915].

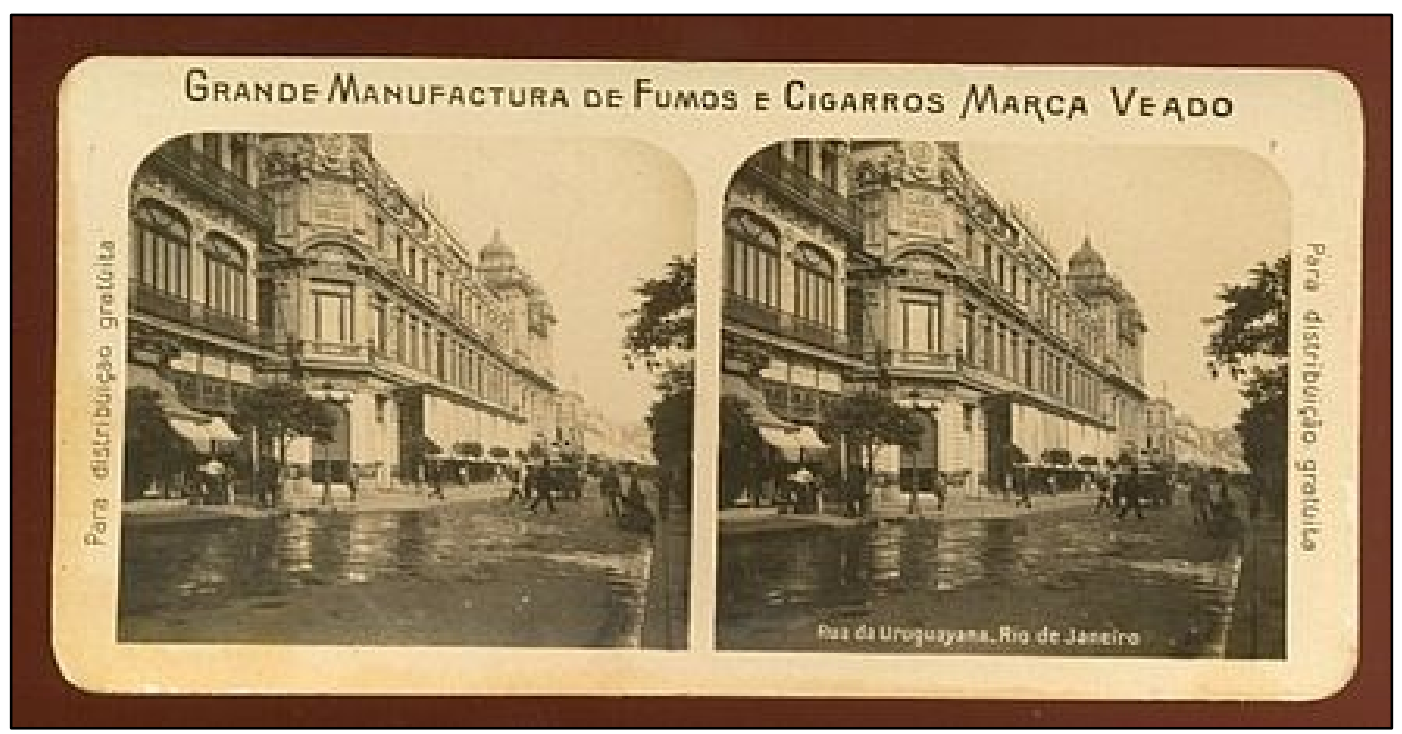

Fonte: [Cartão Marca Veado]. [1890-1915]. Brasil Livros. (Site). Disponível em: http://www.brasillivros.com.br/peca.asp?ID=2372269. Acesso em: nov. 2019;

Também nesse período, outro editor de cartões estereoscópicos surgiu no Rio de Janeiro. Estabelecida na Rua do Ouvidor, a firma Rodrigues \& Co. contratou fotógrafos anônimos que fizeram diversos registros da cidade para a produção de vistas estereoscópicas. Os cartões eram distribuídos como brinde por firmas como a Papelaria e Livraria Gomes Pereira. Cerca de 100 imagens foram produzidas pela empresa que constituiu um retrato exemplar da cidade do Rio de Janeiro e seus arredores. ${ }^{36}$ Atualmente é possível encontrar parte da produção da Rodrigues \& Co. no acervo do Arquivo Nacional, na Coleção de Fotografias Avulsas. São 70 vistas estereoscópicas tomadas das cidades do Rio de Janeiro, Petrópolis e Niterói, que retratam seus logradouros, praças, monumentos e prédios (Figura

\footnotetext{
34 "Turismo estereoscópico" é termo utilizado para se referir à observação e fruição de estereoscopias de tema turístico.

${ }^{35}$ PARENTE, José Inácio. A Estereoscopia no Brasil. Op. cit., p. 53.

${ }^{36}$ Ibidem, p. 72.
} 
6). ${ }^{37}$ A série de fotografias da Exposição de 1908, em comemoração ao centenário da Abertura dos Portos às Nações Amigas é um dos destaques da coleção.

Figura 6 - Central do Brasil, por Rodrigues \& Co., [1890-1910].

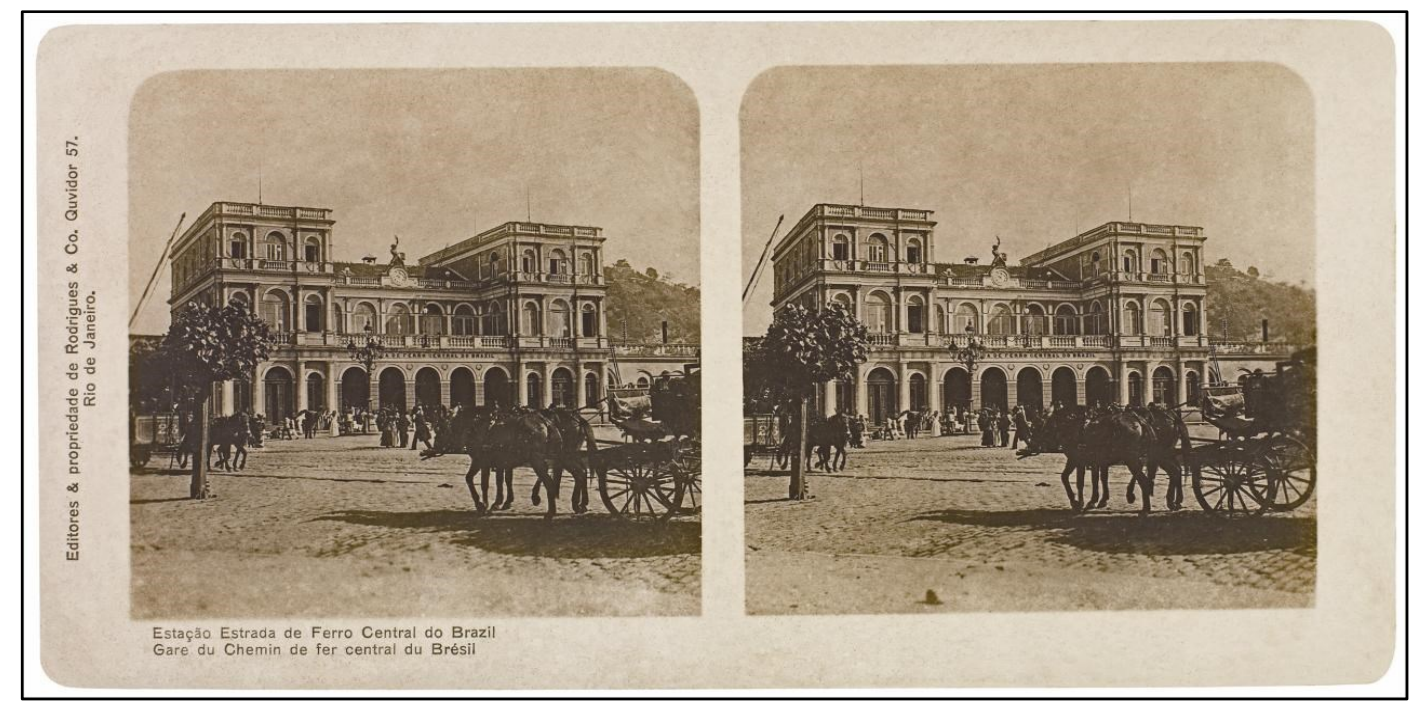

Fonte: ARQUIVO Nacional - Rio de Janeiro. Fundo Fotografias Avulsas. RODRIGUES \& Co. Central do Brasil. [1890-1910].

A cidade do Rio de Janeiro passou, nas primeiras décadas do século XX, por intensas transformações na sua forma urbana. Com o intuito de moldar a cidade à imagem e semelhança das metrópoles europeias, entre 1902 e 1906 o presidente Rodrigues Alves, em parceria com o prefeito Francisco Pereira Passos, deu início à uma política de reformulação da cidade, adequando-a à nova lógica capitalista que se estabelecia com o fim do sistema escravista e da monarquia. A fim de montar uma cidade que fosse de fato a capital do maior produtor de café do mundo, as principais ruas do centro foram alargadas, rios foram canalizados, praças foram embelezadas e uma nova avenida foi criada. Ligando o centro à zona sul da cidade, a Avenida Central foi inaugurada em 1904, substituindo a Rua do Ouvidor em importância e sofisticação. Também um novo porto foi construído, completando assim, a maior reforma de planejamento urbano já existente. ${ }^{38}$

Podemos dizer que as edições estereoscópicas da Marca Veado e da Rodrigues \& Co. possuíam um objetivo similar ao das produções do período anterior, que era o de divulgar um Brasil moderno e civilizado. Entretanto, estes novos editores divulgavam não mais as maravilhas do império, mas sim aquelas promovidas pelo governo republicano recém proclamado. Nesse sentido, ganharão destaque nestas estereoscopias, mais uma vez, as construções monumentais da capital da república, especialmente aquelas inauguradas pelo novo regime. A Avenida Central, seus edifícios monumentais - como o Palácio Monroe e o

37 ARQUIVO Nacional - Rio de Janeiro. Fundo Fotografias Avulsas. Referência: BR RJANRIO.02.0.FOT.444/445/446.

38 BENCHIMOL, Jayme Larry. Pereira Passos, um Haussman Tropical. Rio de Janeiro: Biblioteca Carioca, 1992. 
Theatro Municipal, inaugurados respectivamente em 1904 e 1909 -, suas lojas e seus transeuntes. A Avenida Beira Mar - também recém inaugurada - e os modernos automóveis que por ela circulavam. Além da já mencionada Exposição Universal de 1908, primeira do gênero a ser realizada na era republicana, cujo objetivo principal era justamente apresentar a nova capital às diversas autoridades locais e estrangeiras que a prestigiaram.

\section{O sistema Verascope e o desenvolvimento do amadorismo estereoscópico}

Apesar das iniciativas empresariais do Conde de Agrolongo e da Rodrigues \& Co. é no campo amador que vai surgir o material estereoscópico brasileiro mais interessante. Isso porque, na década de 1890 um novo sistema de produção de fotografias em relevo vai surgir no mercado. Era o sistema Verascope, produzido pela fábrica francesa Maison Jules Richard, que rapidamente se tornou febre em todo o ocidente. O sistema impôs-se no mercado fotográfico como um padrão por sua praticidade e pelo sistema integrado de filme e chapas de vidro, câmera e visor estereoscópico.

Segundo Gavin Adams, o surgimento do Verascope no mercado propiciou o advento de uma nova era na fotografia estereoscópica por estimular a prática amadora da atividade. No Estado do Rio de Janeiro encontram-se quatro das maiores coleções de estereoscopias produzidas no Brasil. A Coleção Sanson, do Museu Imperial, a Coleção Guilherme Santos do Instituto Moreira Salles, a Coleção Guilherme Santos do Museu da Imagem e do Som e a Coleção Guilherme Santos do acervo particular de Fichel Davit Chargel. ${ }^{39}$

A Coleção Sanson, reúne 1.374 fotografias estereoscópicas de vidro produzidas entre os anos de 1900 e 1930, pelo fotógrafo amador Octávio Mendes de Oliveira Castro (1874-1935). A coleção foi doada ao Museu Imperial pelo casal Luiz Alberto de Sanson e Maria Lúcia David de Sanson, descendentes do fotógrafo, em 2005 e 2009. Atualmente é considerada um dos mais significativos registros históricos do Arquivo Iconográfico do Museu Imperial. ${ }^{40}$

\footnotetext{
${ }^{39}$ ADAMS, Gavin. A mirada estereoscópica e... Op. cit., p. 19; SANTOS, Ma. Isabela M. dos. A mirada estereoscópica de... Op. cit.

40 Coleção de fotografias do Museu Imperial é reconhecida como patrimônio nacional. Museu Imperial. (Site). Publicado em: 2 dez. 2013. Disponível em: http://museuimperial.museus.gov.br/imprensa/salade-imprensa/4907-colecao-de-fotografias-do-museu-imperial-e-reconhecida-como-patrimonionacional.html. Acesso em: 23 jul. 2018.
} 
Figura 7 - Palácio Monroe, por Octávio Mendes de Castro, 1922.

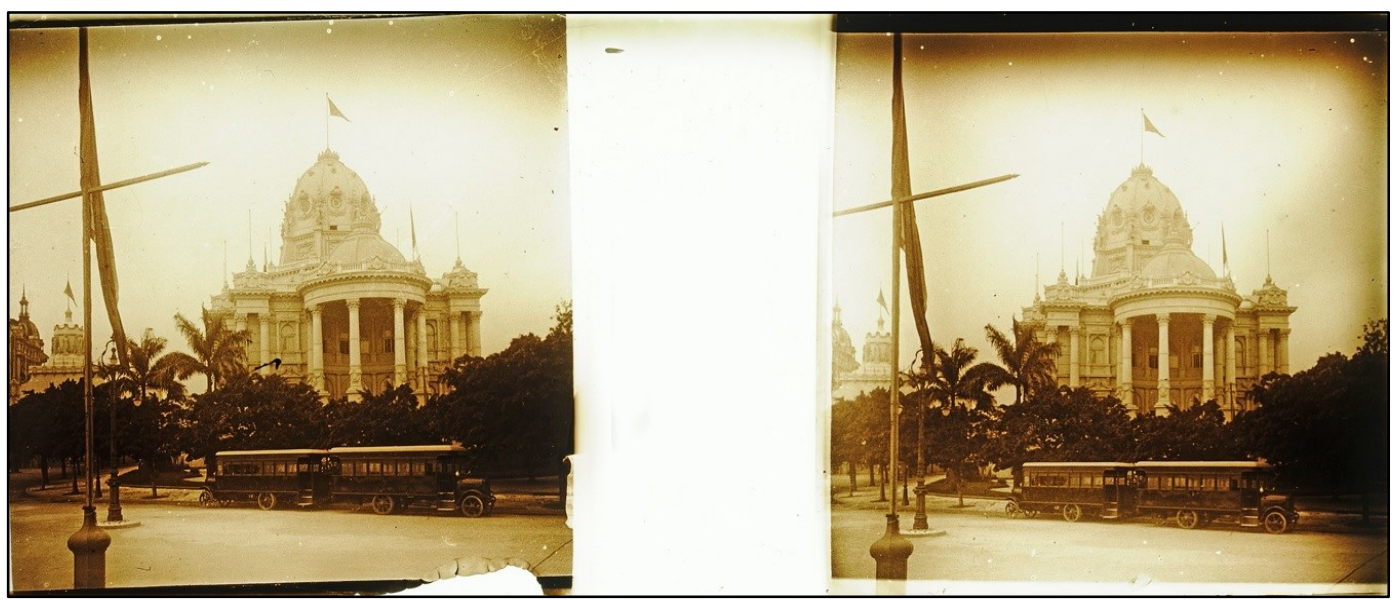

Fonte: MUSEU Imperial. Coleção Sanson. CASTRO, Octávio Mendes de. Palácio Monroe. 1922.

Esta coleção guarda muitas semelhanças com aquela produzida por Guilherme Santos. A primeira característica comum é o sistema utilizado para fotografar. Ambos os fotógrafos utilizavam as câmeras do sistema Verascope e revelavam suas imagens em chapas de vidro do mesmo sistema. A outra semelhança diz respeito aos temas fotografados pelos dois autores. Segundo informações retiradas no sítio eletrônico do Museu Imperial, a coleção de Octávio Mendes de Castro possui:

\begin{abstract}
Imagens da vida doméstica e privada de uma família aristocrática, com seus passeios, viagens e eventos sociais, juntam-se aos registros de importantes eventos ocorridos no Rio de Janeiro, como a grande exposição nacional de 1908 e a exposição internacional de 1922, e de transformações econômicas, como a construção de praças, edifícios e abertura de estradas de ferro e de rodagem em diferentes partes da federação. Como resultado, a "Coleção Sanson" documenta a natureza exuberante do país e o desenvolvimento arquitetônico, urbanístico e paisagístico de diversas cidades do Brasil e do exterior sob o olhar sensível de um apaixonado fotógrafo amador [...] O fotógrafo teve o privilégio de observar e documentar [...] as propriedades da família com suas edificações, festejos, empregados e animais; as viagens no Brasil e no exterior; os eventos cívicos, políticos e religiosos; o desenvolvimento urbano e, principalmente, a vida social com seus hábitos e costumes no início do século XX. ${ }^{41}$
\end{abstract}

Santos também realizou registros das exposições de 1908 e 1922, bem como documentou as transformações urbanas da cidade do Rio de Janeiro do início do século XX. A natureza exuberante do país e os aspectos arquitetônicos e paisagísticos de diversas cidades do Brasil também podem ser observados nas estereoscopias de Santos e, sobretudo, os eventos cívicos, políticos e religiosos são um capítulo a parte da sua obra.

Outra característica que aproxima os dois fotógrafos é a condição social privilegiada da qual gozavam. Guilherme Santos era herdeiro de uma famosa joalheria carioca e representante dos cofres belgas da marca Fichet no Brasil. Octávio de Castro, por sua vez,

${ }^{41}$ Coleção de fotografias do Museu Imperial é reconhecida como patrimônio nacional. Museu Imperial. (Site). Publicado em: 2 dez. 2013. Disponível em: http://museuimperial.museus.gov.br/imprensa/salade-imprensa/4907-colecao-de-fotografias-do-museu-imperial-e-reconhecida-como-patrimonionacional.html. Acesso em: 23 jul. 2018. Grifo nosso. 
tinha origem aristocrática, filho do barão de Oliveira Castro, industrial e figura proeminente do Império do Brasil, e genro do renomado engenheiro João Teixeira Soares, responsável por inúmeras construções de estradas de ferro do país.

A posição social dos fotógrafos amadores que destacamos vai ao encontro dos perfis apontados por diversos pesquisadores da história da fotografia. Segundo Pereira, desde os mais antigos manuais é possível encontrar uma nítida polarização entre fotógrafos profissionais e amadores: "o amador provinha das mais altas classes sociais, tinha cultura artística e técnica, sendo inventor de novos processos". ${ }^{42}$ Entretanto, a partir da década de 1880 , com a entrada das câmeras e equipamentos Kodak no mercado, grandes contingentes provenientes das "classes médias" passarão a se incluir neste hall. Dentro deste contexto, inicia-se um quadro de disputa simbólica de grupos que não queriam perder o espaço de distinção há muito tempo reconhecido socialmente. Em geral, todos os diferentes grupos que revindicavam a hegemonia sobre o que poderia ser classificado como fotografia amadora, criticavam os usuários de câmeras Kodak ou similares. Assim, "nesse contexto de muitas dicotomias, surgia mais acirradamente a necessidade de diferenciar os campos, dos amadores entre si em relação aos profissionais". ${ }^{43}$

Um dos campos mais relevantes dessa disputa era o dos fotoclubistas. Este grupo tinha como objetivo mais importante colocar a fotografia no mesmo patamar das Belas Artes. No Brasil, o fotoclubismo também terá sua expressão. Com surgimento do Photo Club do Rio de Janeiro em 1910, a concepção artística da fotografia vai começar a ganhar impulso. Tomando como diretriz estética o movimento pictorialista internacional ${ }^{44}$ o fotoclubismo brasileiro vai levar em consideração a tradição figurativa existente na pintura e expressa pela Escola Nacional de Belas Artes. ${ }^{45}$

Primeiro fotoclube a se organizar de maneira efetiva no país, o Photo Clube Brasileiro se estabelece como um espaço de crítica tanto aos fotógrafos profissionais, quanto aos amadores denominados de "meros batedores de chapa". Fenômeno internacional de grande disseminação, este era um movimento típico dos núcleos urbanos mais desenvolvidos. No Brasil, seu crescimento seguiu o ritmo da expansão dos centros urbanos e das sociedades burguesas. De caráter predominantemente elitista, os fotoclubistas cultuavam a estética acadêmica e sobrevalorizavam a técnica fotográfica. A condição do fotógrafo clubista era, em geral, do profissional liberal que podia se dedicar à fotografia em suas horas vagas, já que

\footnotetext{
42 PEREIRA, Adriana M. P. Martins. A cultura amadora na virada do século XIX: A fotografia de Alberto Sampaio (Petrópolis/Rio de Janeiro, 1888-1914). 2010. Tese (Doutorado em História Social) - Faculdade de Filosofia, Letras e Ciências Humanas da Universidade de São Paulo, São Paulo, p. 65.

${ }^{43}$ Ibidem, p. 66.

${ }^{44}$ O Movimento Pictorialista consistiu em uma corrente radical da arte fotográfica, surgida nos anos de 1850 com Paul Périer, um dos vice-presidentes da Sociedade Francesa de Fotografia. O movimento se pronunciava contra a vulgarização das obras de arte através da fotografia e recusava o registro, o automatismo, a imitação servil, a máquina, a cópia literal e defendia que, para abrir a fotografia para a arte, o fotógrafo-artista deveria intervir diretamente na imagem, inclusive com a mão.

45 Segundo Mello: "a percepção do pictorialismo no Brasil leva em consideração a tradição figurativa existente na pintura brasileira, expressa pela Escola Nacional de Belas-Artes, associada ao trabalho dos pintores de panoramas tais como Leadro Joaquim e Vitor Meirelles e aos pintores paisagistas como Georg Grimm, Castagneto e Henri Vinet". MELLO, M. Teresa B. de. Arte e fotografia: O Movimento Pictorialista no Brasil. Rio de Janeiro: Funarte, 1998, p. 37.
} 
possuía uma condição financeira confortável. O fotoclube fazia, portanto, parte da identidade cultural do pequeno-burguês. ${ }^{46}$ Guilherme Santos filiou-se ao Photo Clube Brasileiro em 1925 e encaixava-se perfeitamente no perfil dos amadores fotoclubistas das primeiras décadas do século XX. ${ }^{47}$

Independentemente de serem sócios ou não de fotoclubes, podemos dizer que há algumas características que, nas palavras de Pereira, dão à fotografia amadora "inteligibilidade e interesse", uma espécie de pacto que estaria na "contribuição do lúdico". Não tem a ver necessariamente com uma função mais documental ou representativa da fotografia, e sim com os usos feitos das imagens. A diferença principal entre o profissional e o amador, nesse sentido, não está na competência técnica do fotógrafo e nem no domínio de conhecimentos de padrões estéticos, uma vez que para o amador, fotografia não é mercadoria, ele não precisa disso para viver. Suas fotos não circulavam comercialmente, e sim entre familiares e amigos. ${ }^{48}$

Sobre o amadorismo fotográfico, Adams lembra da importância do álbum de família como um aparato desenvolvido pela indústria fotográfica do século XIX. No álbum, o regime de testemunhos fotográficos de encenações sociais se consolida. A fotografia amadora estereoscópica atuava de maneira semelhante ao álbum de família, porém com o aspecto adicional de inserir a família num universo visual moderno. Pela primeira vez o observador tinha a possibilidade de ver a si mesmo dentro deste novo espaço formado pela "mirada estereoscópica". ${ }^{9}$ "A estereoscopia amadora permite uma auto-inserção do membro familiar como ator na construção deste olhar moderno, ou pelo menos imaginar-se habitante do mundo modernamente construído". Eis então a grande novidade da estereoscopia amadora: a autoimagem inserida dentro do contexto das transformações urbanas, reconstruída como sensação visual-tátil. Se a imagem turística comercial já possibilitava um "eu estive lá" e um "eu vi isto", "a imagem amadora conflui na própria imagem os dois testemunhos, inscrevendo o fotógrafo e seus parentes em 'museu imaginário' particular". ${ }^{50}$

Em termos gerais, no entanto, podemos afirmar que os fotoestereoscopistas amadores guardavam em comum a preferência pela vida doméstica e pelos aspectos urbanos. Já mencionamos que Santos e Castro realizaram inúmeros registros de aspectos naturais e urbanos de diversas cidades do Brasil. Não obstante, um levantamento realizado por Adams mostra que os fotógrafos paulistas privilegiavam em seus passeios estereoscópicos a produção de vistas de espaços e edifícios públicos de cidades como Rio de Janeiro, São Paulo e Santos, com visível influência da linguagem visual do turismo. Desse modo, percebe-se que os amadores lançavam mão de linguagens visuais que encontravam-se em circulação à época, nos mais diferentes formatos: cartões-postais, gravuras, ilustrações, mas, especialmente no

${ }^{46}$ COSTA, Helouise; RODRIGUES, Renato. A fotografia moderna no Brasil. São Paulo: Cosac \& Naify, 2004 , p. 28.

47 SANTOS, Ma Isabela M. dos. A mirada estereoscópica de... Op. cit., p. 130-133.

48 PEREIRA, Adriana M. P. Martins. A cultura amadora... Op. cit., p. 246-247.

${ }^{49}$ A "mirada estereoscópica" é termo cunhado por Gavin Adams para caracterizar a operação visual que a observação de uma estereoscopia exige e que "envolve o alinhamento de um corpo observador em relação a um aparato de visualização e um tipo particular de concentração para a produção de sensação de volume a partir de duas imagens". ADAMS, Gavin. A mirada estereoscópica e... Op. cit., p. 3.

${ }^{50}$ ADAMS, Gavin. A mirada estereoscópica e... Op. cit., p. 20-21. 
formato estereoscópico definido pelas empresas especializadas.

\title{
Século XX: a produção amadora de Guilherme Santos e a cidade do Rio de Janeiro como paisagem ideal
}

Guilherme Antonio dos Santos (1871-1965) foi o maior e mais importante fotógrafo amador a atuar com a técnica estereoscópica no Brasil. Sua obra encontra-se, atualmente sob a guarda de três diferentes instituições. No Museu da Imagem e do Som, a Coleção Guilherme Santos possui mais de 9 mil vistas diapositivas e mais de 17 mil negativos em vidro. Na coleção pertencente ao Instituto Moreira Salles, existem cerca de 3 mil vistas, aproximadamente a mesma quantidade existente na coleção privada de Davit Fichel, que constitui o acervo do Museu de Comunicação e Costumes que o colecionador pretende inaugurar na Ilha de Paquetá. ${ }^{51}$

Ao longo de mais de cinco décadas de atividade estereoscópica - entre 1905 e 1957-, Guilherme Santos fotografou diversas cidades brasileiras sudestinas. Entre elas, as cidades mineiras de Belo Horizonte, Caxambu, Cambuquira, Lambari, Poços de Caldas e São Lourenço, a capital paulista e as cidades fluminenses de Niterói, Petrópolis e Teresópolis. No entanto, em um levantamento realizado no ano de 2013 no acervo do Museu da Imagem e do Som, ficou clara preeminência da cidade do Rio de Janeiro sobre as demais. ${ }^{52}$

De acordo com reportagem do jornal O Globo no ano de 1964:

\begin{abstract}
O Sr. Guilherme dos Santos, que tem 92 anos de idade, é um apaixonado do Rio e diz que resolveu fazer a coleção depois de observar que na capital francesa só eram mostrados os aspectos negativos do Brasil. Entre as numerosas preciosidades fotográficas do Sr. Guilherme dos Santos, encontram-se fotos do Rei Alberto da Bélgica no Brasil, do Presidente Vargas de cartola a frente do Palácio Guanabara, além de milhares de cenas do Rio no começo do século. Por exemplo, dos banhos de mar na Praia do Flamengo, com as senhoras e senhoritas dentro de maiôs compridos, que desciam até os joelhos. ${ }^{53}$
\end{abstract}

Em linhas gerais, podemos dizer que a produção estereoscópica de Guilherme Santos se dividia em dois conjuntos analíticos principais: fotografia artística e fotografia documental. Esta separação não está dada em suas coleções de forma estanque, mas o próprio fotógrafo defendia que seu trabalho estava imbuído de um caráter "artístico-documental". ${ }^{54}$ Desse modo, em determinadas séries é possível detectar a predominância de um viés pictórico, ao modo do que era praticado pelos fotógrafos amadores fotoclubistas, enquanto em outras predomina a linguagem do foto-jornalismo, mais alinhada às fotografias que circulavam nas revistas ilustradas da primeira metade do século XX. Na obra de Guilherme Santos estas duas

\footnotetext{
${ }^{51}$ SANTOS, Ma. Isabela M. dos. A mirada estereoscópica de... Op. cit., p. 282-284.

52 Cf.: SANTOS, Ma. Isabela M. dos. Cenas Cariocas. O Rio de Janeiro através das estereoscopias de Guilherme Santos (1910-1957). 2014. Dissertação (Mestrado em História) - Instituto de Ciências Humanas e Filosofia da Universidade Federal Fluminense, Niterói (RJ).

${ }^{53}$ O Globo, Rio de Janeiro, 7 jan. 1964, p. 5.

${ }^{54}$ SANTOS, Ma. Isabela M. dos. A mirada estereoscópica de... Op. cit., p. 114.
} 
perspectivas, ora sobrepostas, ora intercaladas, dão origem à "mirada estereoscópica", essência de sua obra.

A estereoscopia não era reconhecida como prática fotográfica de estúdio, constituindo sua cultura visual "essencialmente junto das paisagens naturais, das cidades e dos monumentos". Nesse sentido, a fotografia de Guilherme Santos nasce documental já em sua essência, para além das contribuições recebidas dos precursores da fotografia nacional. Dentre as temáticas privilegiadas pelo fotoestereoscopista, destacam-se os diversos logradouros da Zona Sul da cidade, principalmente as praias e seus banhistas; os parques e as praças como o Jardim Botânico, o Campo de Santana, a Quinta da Boa Vista e o Passeio Público; a exuberância da natureza da cidade com sua cadeia e montanhas e ícones imagéticos como o Pão de Açúcar e o Corcovado; mas também os eventos sociais e solenes como o carnaval de rua, as visitas oficiais e as exposições internacionais. Os aspectos sociais consistiram, portanto, numa preocupação evidente do trabalho de Guilherme Santos.

Entre documentos e obras de arte, um tipo de fotografia que Guilherme Santos apreciava muito produzir eram as do luar e do nascer ou pôr do sol. Estas séries, eram chamadas pelo próprio fotógrafo de "reflexos" e foram realizadas várias vezes ao longo de sua atividade fotográfica. Nelas, ele se utilizava dos efeitos da luz do sol e da lua refletidos na Baía de Guanabara, ou em qualquer tipo de espelho d'água, como por exemplo, a Lagoa Rodrigo de Freitas ou o lago da Quinta da Boa Vista. Um dos locais preferidos do fotógrafo para a produção de vistas deste tipo era a Praia do Retiro Saudoso, no bairro do Caju. No ano de 1921, por exemplo, Santos produziu uma série de treze fotografias naquele local, todas com as palavras "por do sol" ou "cair da tarde" e "effeito de luz" nas legendas (Figura 8). As vistas da série são bem similares, têm sempre como destaque o reflexo do sol nas águas da baía, e se diferenciam umas das outras por pequenos detalhes, como a presença de elementos como embarcações, árvores, ou vegetação. ${ }^{55}$

\footnotetext{
${ }^{55}$ MUSEU da Imagem e do Som. Coleção Guilherme Santos, Série "Retiro Saudoso, 1921". Referência:
} GSEP:4665- 4775. Grifo nosso. 
Figura 8 - Retiro Saudoso, por Guilherme Santos, 1921.

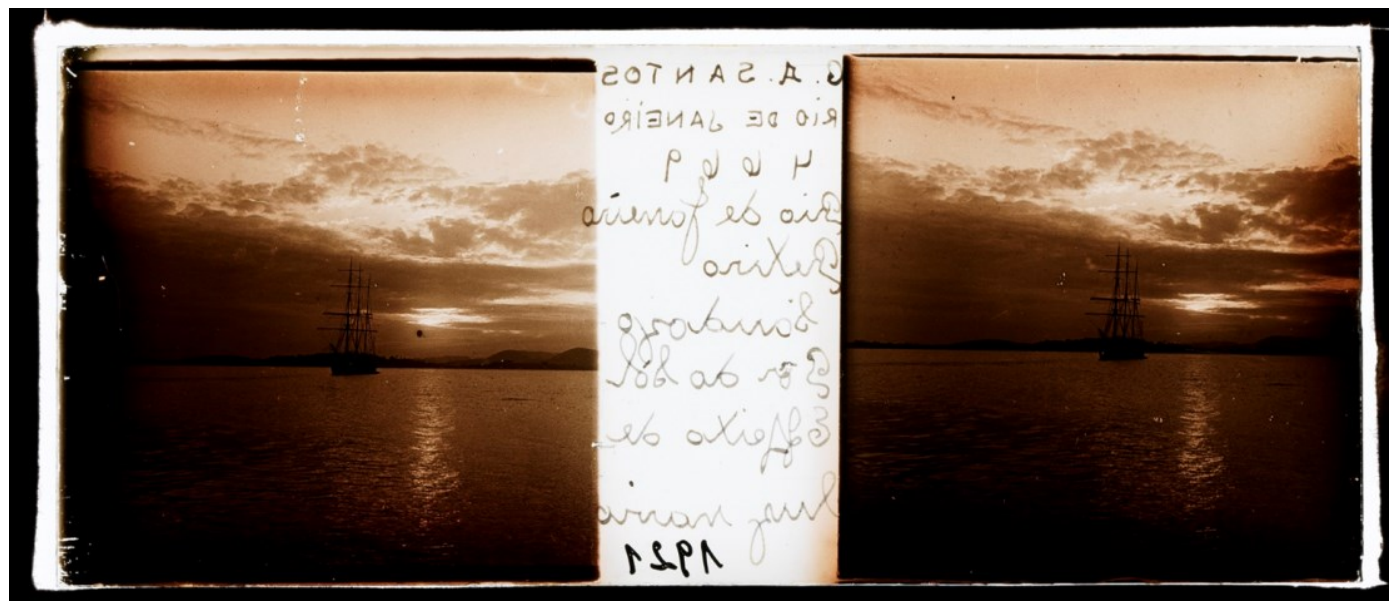

Fonte: MUSEU da Imagem e do Som. Coleção Guilherme Santos. SANTOS, Guilherme. Retiro Saudoso. 1921.

Séries do pôr do sol foram produzidas por Guilherme Santos também em locais de mar aberto, como as praias de Copacabana ou Ipanema. Neste último, era comum que o fotógrafo aproveitasse da geografia dos morros Dois Irmãos e da Pedra da Gávea para produzir composições de luz e de sombra. Ele também produziu uma quantidade relevante de panoramas noturnos da cidade do Rio de Janeiro cujo destaque era a iluminação artificial, principalmente de pontos ao redor da Baía de Guanabara, como a enseada de Botafogo. Os monumentos arquitetônicos da cidade, amplamente documentados à luz do sol, foram também alvos de capturas noturnas.

Segundo Maria Pacce Chiavari:

no início do século $X X$, no Brasil, o desenvolvimento da técnica fotográfica contribuiu para o surgimento de uma cultura visual ligada especificamente à cidade e capaz de documentar a sua história, de acordo com as exigências colocadas pela moderna sociedade. Embora a fotografia, desde o período do Império, como demonstra Pedro Vasquez (Vasquez, 2003, p. 54-55), assuma peso no âmbito da edificação iconográfica da Capital do Brasil, o novo regime republicano faz dessa técnica a linguagem oficial de comunicação e divulgação do próprio governo. ${ }^{56}$

Guilherme Santos não atuava como fotógrafo oficial do regime republicano. Entretanto, ele nunca escondeu que entendia a fotografia como uma missão civilizatória e patriótica. Em entrevista concedida ao Boletim de Belas Artes no ano de 1946, quando perguntado sobre o motivo que o levou a "documentar tão cuidadosamente" o Morro do Castelo, "condenado a desaparecer", ele respondeu: "Interesse puramente espiritual, isto é, sentimental e patriótico". ${ }^{57}$ Do mesmo modo, quatro anos depois, em entrevista concedida a Revista A Noite, afirmou:

${ }^{56}$ CHIAVARI, Maria Pace. O mar, ícone e indício na fotografia pública do Rio de Janeiro (1906-1922). In: MAUAD, Ana Maria (org.). Fotograficamente Rio: A cidade e seus temas. Rio de Janeiro: FAPERJ, 2016, p. 15.

57 Boletim de Belas Artes, Rio de Janeiro, n. 18, jun. 1946, p. 167-168. 
um ideal dominou meu sentimento de brasileiro: fazer um arquivo de fotografias que um dia provasse que o Brasil não era aquilo que estava sendo apresentado: Minhas fotografias mostrariam em quadros, com expressão artística, um Brasil adiantado e cheio de atrações, civilizado, habitado por uma raça superior. ${ }^{58}$

Portanto, por mais que Guilherme Santos não fosse fotógrafo oficial da república, sua fotografia possuía sim, um caráter oficioso. Assemelhava-se, sob muitos aspectos, às imagens oficiais, através das quais foi construída a imagem-modelo da Capital Federal, principalmente a partir de 1902, com a posse do Presidente Rodrigues Alves. Ao analisar as representações fotográficas constituintes dos álbuns de fotografias institucionais da Capital Federal do início do século XX, Chiavari afirma que com o clima de "regeneração da capital", surge um mercado que induz a elaboração de uma imagem fotográfica baseada no uso político da fotografia. Um dos álbuns analisados pela autora é o "Álbum da Cidade do Rio de Janeiro comemorativo do $1^{\circ}$ Centenário da Independência do Brasil, 1822-1922".59 Neste álbum:

A visualidade da então capital Federal, refletida nas suas imagens fotográficas, permite verificar o processo de finalização dos projetos implementados durante a gestão do governo da Primeira República. Na capa, a menção à prefeitura do Distrito Federal, como entidade responsável pela edição do álbum, confere às imagens apresentadas o estatuto de "fotografias oficiais", independente da intenção do autor das fotos. ${ }^{60}$

A autora destaca como uma grande novidade do álbum comemorativo do $1^{\circ}$ Centenário da Independência, a presença de vistas noturnas. "Embora, desde a primeira metade do século XIX, a iluminação de Paris representasse um mito no mundo inteiro, no Rio de Janeiro, a imagem de Paris ville lumière torna-se referência do gosto Belle Époque no momento das grandes transformações urbanas." Porém, no contexto carioca, o uso de vistas noturnas poderia assumir diferentes funções, sendo possível identificar uma escolha seletiva das áreas a serem modernizadas no âmbito do plano urbano. Assim, é possível verificar, em uma vista noturna tomada no bairro de Botafogo, que a intensidade de iluminação produzida pela rede elétrica aumenta ao se aproximar do litoral. "Por tal moderna infraestrutura ser limitada, na época, às áreas mais enriquecidas da cidade, sua presença em Botafogo, assinala esse bairro como um dos mais favorecidos e elitizados". ${ }^{61}$

Não por acaso, a parte das fotografias noturnas de Guilherme Santos foram tomadas justamente nos bairros de Botafogo e Copacabana, os mais iluminados à época. As outras foram tomadas durante eventos oficiais. Um deles, justamente a festa do Centenário da Independência (Figura 9), mencionada por Chiavari, cujo ápice foi a Exposição Internacional de 1922, que se realizou no novo espaço da cidade que surge com a demolição do Morro do Castelo. Para além dos objetivos de afirmar uma imagem do país internamente, a exposição tinha o intuito de projetá-lo no cenário internacional como uma nação moderna e civilizada.

\footnotetext{
${ }^{58}$ Revista A Noite, Rio de Janeiro, 10 ago. 1950, p. 20. (Grifo nosso).

${ }^{59}$ CHIAVARI, Maria Pace. O mar, ícone e... Op. cit., p. 17.

${ }^{60}$ Idem.

${ }^{61}$ Idem
} 
Figura 9 - Centenário da Independência do Brasil, por Guilherme Santos, 1922.

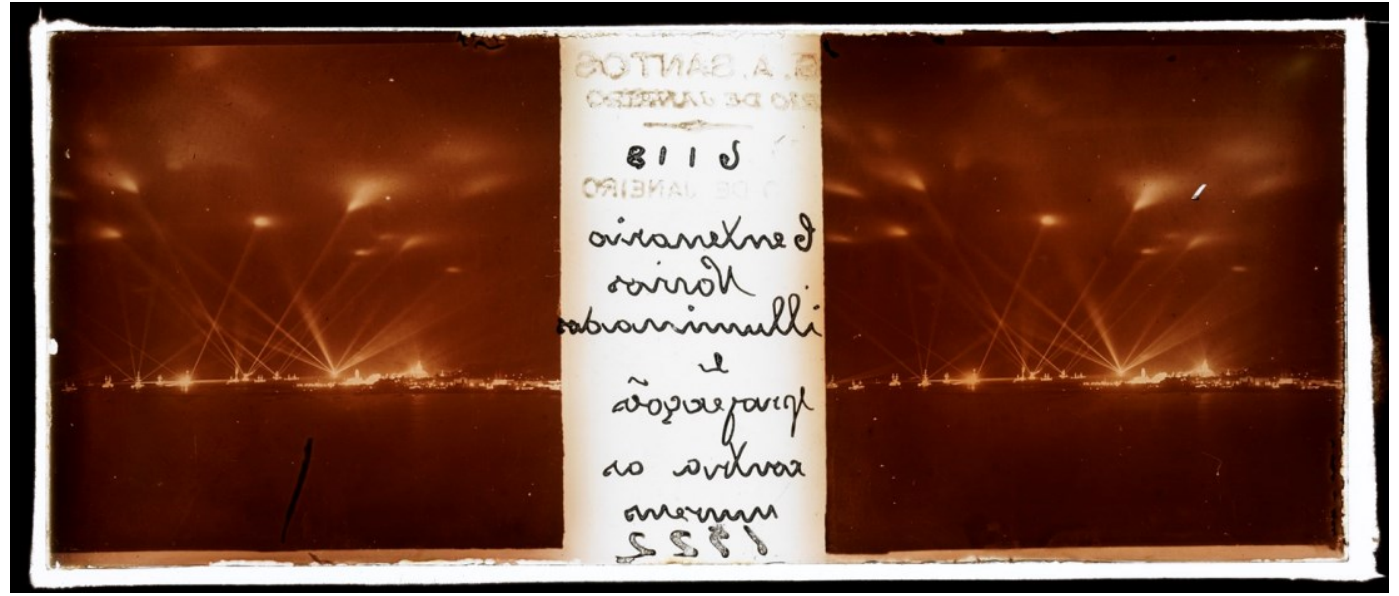

Fonte: MUSEU da Imagem e do Som. Coleção Guilherme Santos. SANTOS, Guilherme. Centenário da Independência do Brasil. 1922.

Nascido no Rio de Janeiro, no ano de 1871, ao longo de seus 95 anos Guilherme assistiu um processo drástico de mudanças polítcas e culturais, mas especialmente uma mudança radical na forma de percepção do tempo, que era agora uma percepção fragmentária, "obediente ao império de hoje e à restrição do presente ao instante a que se assistia então, pendendo para a crônica ou o instantâneo fotográfico". ${ }^{62}$ Esta mudança na percepção do tempo que vai exigir cada vez mais imagens técnicas refletirá, por sua vez, o desejo de modernização que vai impulsionar as reformas urbanas e sanitárias que vão colocar abaixo símbolos da cidade que pareciam, até então, intocáveis. Por esta razão, Guilherme empreendeu uma cobertura detalhada do Morro do Castelo às vésperas de sua demolição definitiva e, quando perguntado sobre as razões que o levaram aquele ato, respondeu: "Não tendo forças para impedir o fato, procurei gravar do melhor modo o trecho a ser destruído, para minorar esse desastre. Hoje possuo em meu arquivo aspectos do Brasil que ninguém mais poderá ver senão através de minhas chapas". ${ }^{63}$

Santos parecia assim ter consciência de que a civilização da qual participamos existe com evidência nos utensílios que produzimos e utilizamos ao se iniciar na fotografia estereoscópica. O comerciante acreditava, sobretudo, no poder pedagógico de suas estereografias. Fotografava com um grande apego ao passado, que não é único, mas vários

\footnotetext{
${ }^{62}$ SUSSEKIND. Flora. Cinematógrafo de Letras. Literatura, técnica e modernização no Brasil. São Paulo: Companhia das Letras, 1987, p. 99.

${ }_{63}$ Boletim de Belas Artes, Rio de Janeiro, n. 9, set. 1945. Em 1904, durante a gestão de Pereira Passos, parte do Morro do Castelo já havia sido demolida para a abertura da Avenida Central. Foi na gestão de Carlos Sampaio, em 1921, que teve início a destruição definitiva do Morro, marco de fundação da cidade, porém considerado símbolo do passado colonial português. A decisão foi tomada, mais uma vez, sobre o pretexto de higienização e modernização da cidade, uma vez que acreditava-se que a colina era responsável pela proliferação dos "miasmas" causadores das doenças que constantemente se abatiam sobre seus habitantes. No lugar do Morro, foi construída a Esplanada do Castelo, onde em 1922, ocorreria a Exposição Internacional de 1922, em comemoração ao Centenário da Independência do Brasil.
} 
passados sobrepostos: seu próprio passado vivido na infância, nos tempos da monarquia; o "passado de glórias" da cidade do Rio de Janeiro, fundada no Morro do Castelo, a "Acrópole brasileira"; o passado que ainda estava por vir quando se iniciou na fotografia; o passado da estereoscopia, que ao longo do século XX foi se tornando obsoleta. Apegado à sua crença, com a fotografia estereoscópica, Guilherme fazia surgir "o progresso através da tradição que desaparece". ${ }^{64}$

Não obstante, o passado que Guilherme Santos fez questão de gravar em chapas estereoscópicas estava imbuído de um viés ideológico bem claro. Ainda que não trabalhasse para nenhum órgão estatal, não fosse funcionário de nenhum jornal e nem mesmo costumasse comercializar suas vistas, elas tinham uma função bem definida para o fotógrafo: mostrar que o Brasil não era um país de selvagens. Esta imagem que Guilherme Santos tentou construir sobre o Brasil no exterior era obviamente uma imagem idílica. Era a imagem de um país moderno, civilizado, habitado por uma população de maioria branca, bem educada, que sabia receber os ilustres estrangeiros que por aqui passavam, bem como organizar eventos internacionais de grande porte. Esta imagem geral do país, excluía de suas vistas os bairros do subúrbio do Rio de Janeiro, os negros, as favelas já em expansão, a pobreza e a miséria. Bem como, englobava somente a região sudeste e tomava o local, especialmente a capital federal, como o nacional. Logo, tudo que não aparece na fotografia de Guilherme Santos, pode nos revelar ainda mais sobre o viés ideológico de sua obra.

Crendo na objetividade da estereoscopia e carregado de uma missão bem definida desde o princípio, o fotógrafo não se contentou em restringir suas vistas aos poucos observadores de seu círculo familiar e social. Aí temos uma característica fundamental que o diferencia dos demais estereoscopistas. O esforço empreendido por Guilherme Santos não é comparável ao de nenhum outro fotógrafo do tipo e, até mesmo entre os adeptos da fotografia plana é difícil encontrar uma produção tão extensa. Mas, especificamente entre os adeptos da estereografia, sabemos que a maioria das coleções de vistas estereoscópicas produzidas por amadores no Brasil encontram-se ainda hoje em coleções particulares ou foram adquiridas por museus e arquivos públicos muito recentemente, através de negociação com os descendentes dos fotógrafos. ${ }^{65}$ Guilherme, por sua vez, perseguia pelo menos desde a década de 1940, a ideia de vender sua coleção a um museu ou arquivo público e não vai descansar enquanto não alcançar este objetivo.

Esta busca incessante que só termina ao final de sua vida, Guilherme mostra o desejo subjetivo do fotógrafo de se eternizar e tornar sua obra um patrimônio público. O que significa que desejava que ela atuasse na orientação dos indivíduos em um contexto de identidade coletiva, obrigação e poder. Assim, a cobertura documental do fotógrafo pode ser avaliada como um exercício de fotografia pública que tinha o objetivo de associar a informação sobre o evento à fruição estereoscópica.

\footnotetext{
${ }^{64}$ Revista A Noite, Rio de Janeiro, 1 ago. 1950, p. 20.

${ }^{65}$ Cf.: ADAMS, Gavin. A mirada estereoscópica e... Op. cit., Anexo 1 - Coleções Estereoscópicas.
} 
Ora, se a obra de Guilherme Santos não se tornou uma referencia visual nacional - no sentido que poucos são os brasileiros que conhecem suas vistas -, não podemos negar que seu trabalho sempre esteve em consonância com a cultura visual do seu tempo e que, nesse sentido, o fotógrafo ajudou a formar uma memória coletiva acerca do Brasil da primeira metade do século XX e, mais especificamente acerca da cidade do Rio de Janeiro. Não obstante, depois de muitas tentativas, Guilherme consegue finalmente vender sua coleção de vistas estereoscópicas para o poder público no ano de 1964.

Será no Museu da Imagem e do Som (MIS), empreendimento cultural da gestão de Carlos Lacerda no governo do Estado da Guanabra, que a obra de Santos encontrará seu refúgio. Para Lacerda, as estereoscopias de Santos figuravam "uma outra fase do Rio, o Rio da $1^{\text {a }}$ Guerra Mundial, o Rio depois de vencida a febre amarela, o Rio de Antônio Prado Júnior e de Pedro Ernesto, o Rio metrópole moderna, a partir do $1^{\circ}$ Centenário da Independência do Brasil..."66 Nesse sentido, sua coleção de estereoscopias combinava perfeitamente com as intenções de Lacerda para a criação do MIS, intenções essas que se voltarão para a reafirmação do Rio de Janeiro enquanto capital cultural do país, quando da inauguração de Brasília. Ainda de acordo com Lacerda:

O Rio é uma cidade em que todos os brasileiros, ontem, hoje e sempre estarão
como em sua casa. Sabem esses brasileiros que somos uma região sem
regionalismo, pensamos nossos problemas em termos mundiais, além de
continentais, e continentais, além de nacionais. [...] somos a síntese do Brasil
[...] somos a porta do Brasil para o mundo. E somos do mundo a vera imagem
que ele faz de nós [...] somos um povo ecumênico, povo litorâneo, voltado para
o nosso tempo, abraçado com o futuro. Nosso pensamento, profundamente
brasileiro, é internacional. ${ }^{67}$

As singularidades da cidade destacadas pelo governador no trabalho de construção simbólica do Rio serão materializadas no Museu da Imagem e do Som, entendido como um "museu de fronteira" pelo seu caráter de consolidação material e delimitação simbólica de uma identidade cultural local. Será, portanto, pensando em tais moldes identitários que a criação do MIS se dará. Um museu para atuar como "lugar de memória" carioca e, consequentemente, dar novo gás a autoestima da cidade. ${ }^{68}$

Tomando a cidade do Rio de Janeiro como a síntese do Brasil, a coleção Guilherme Santos garante ao público aprender sobre o passado da cidade fora da escola, reforçando "o passado formal pela educação do olhar". ${ }^{69}$ Assim, as vistas estereoscópicas de Santos ganham no MIS as condições ideais para que o passado seja recriado diante do público. É o que Ana Maria Mauad chama de "dimensão pública da experiência visual, que ao colocar o expectador

\footnotetext{
66 MUSEU da Imagem e do Som. Fonoteca. LACERDA, C. A redenção da cidade. Discurso de inauguração do MIS, 3 de setembro de 1965.

67 Idem.

68 MESQUITA, Cláudia. Um museu para a Guanabara. Carlos Lacerda e a criação do Museu da Imagem e do Som (1960-1965). Rio de Janeiro: Folha Seca, 2009, p. 93.

69 MAUAD, Ana Maria. O passado em imagens: Artes visuais e história pública. In: MAUAD, Ana Maria; ALMEIDA, Juniele Rabêlo de; SANTHIAGO, Ricardo. História Pública no Brasil: sentidos e itinerários. São Paulo: Letra e Voz, 2016, p. 90.
} 
face a representação do passado Ihe atribuía uma consciência histórica". ${ }^{70}$

\section{Conclusão}

O Rio de Janeiro, com um espaço tridimensional por natureza, recortado por montanhas, praias e florestas apresentava para a fotografia estereoscópica um estimulante desafio. De cada canto se descortinava uma nova maravilha com diversos planos e fácil sensação de profundidade aproveitando-se desse relevo, as primeiras estereoscopias são verdadeiras "vistas aéreas" feitas dos morros. $^{71}$

Em conjunto com outros dispositivos ópticos, mas especialmente com a fotografia, a estereoscopia foi responsável pelo redimensionamento do olhar dos indivíduos modernos, gozando de certa hegemonia entre as mídias visuais até as primeiras décadas do século XX. Com o surgimento de editoras especializadas a partir da década de 1860, vistas estereoscópicas dos mais variados temas serão produzidas por fotógrafos profissionais enviados para diversas partes do globo, com o objetivo de produzir um verdadeiro inventário do real. Surge o "turismo estereoscópico", um produto que garante ao observador viajar sem sair da poltrona. De caráter eminentemente pedagógico, a estereoscopia era também uma forma de entretenimento das famílias burguesas do ocidente.

No Brasil do Segundo Reinado a técnica também teve uma significativa expressão, especialmente entre os fotógrafos profissionais de grande prestígio na corte. Revert Henry Klumb, fotógrafo da Casa Imperial, foi provavelmente o introdutor da técnica no país, produzindo mais de 200 estereoscopias que contemplavam principalmente as paisagens naturais, os aspectos da urbanização de cidades como Rio de Janeiro e Petrópolis, e o cotidiano da família imperial. A família imperial, por sua vez, pode ser considerada uma das grandes incentivadoras da prática estereoscópica no Brasil, ao utilizar as exposições nacionais e internacionais como os meios de divulgação mais importantes do trabalho dos fotógrafos que atuavam no país.

No alvorecer do século XX o Brasil vai assistir uma verdadeira corrida em direção às imagens técnicas. ${ }^{72}$ Jornais, revistas ilustradas, a indústria publicitária nascente e o cinema, serão os principais responsáveis pela introdução deste tipo de imagem no cotidiano dos brasileiros. Significativo também será o crescimento do número de fotógrafos amadores no país. No campo do amadorismo fotográfico, a fotografia em três dimensões também terá seu espaço. Seguindo uma tendência europeia, representantes da alta burguesia dos grandes centros urbanos como Rio de Janeiro e São Paulo, dedicarão parte de seus momentos de lazer ao colecionismo e à prática da fotografia estereoscópica. Em suas imagens, as cidades brasileiras e a vida cotidiana serão as protagonistas. Dentre elas, uma se destaca no trabalho

\footnotetext{
70 MAUAD, Ana Maria. O passado em imagens... Op. cit., p. 90.

${ }^{71}$ PARENTE, José Inácio. A Estereoscopia no Brasil. Op. cit., p. 29.

72 SUSSEKIND, Flora. Cinematógrafo de Letras... Op. cit., p. 36.
} 
de Guilherme Santos, o maior estereoscopista do país: a cidade do Rio de Janeiro.

Mas não foi Santos o primeiro a perceber a vocação estereoscópica da cidade. Procuramos no espaço deste artigo apresentar ao leitor a trajetória desta técnica hoje tão pouco conhecida e sua relação com o Rio de Janeiro. A história da estereoscopia no Brasil se confunde com a história da estereoscopia na "cidade maravilhosa", assim como o desenvolvimento da estereoscopia se confunde com o desenvolvimento da fotografia. Cidade brasileira onde o daguerreótipo aportou pela primeira vez, não é de se estranhar que aqui tenham se fixado - ainda que por breves períodos - os grandes precursores da fotografia no país. Já nas últimas décadas do século XIX o Rio de Janeiro era o tema predileto da fotografia de paisagem. Seus casarios, costumes, espaços de sociabilidade e natureza exuberante, propiciavam que esse estilo fosse bastante praticado por profissionais de procedências distintas, atraídos pela rica clientela da corte.

A mudança do regime político do país vai propiciar também mudanças na configuração urbana da agora capital federal. A vocação fotográfica da cidade permanece, no entanto. "Reformada e salubre, a cidade ostentava com orgulho sua nova feição, inspirando os mais diversos fotógrafos". ${ }^{73}$ Desde as editoras especializadas até os registros de amadores, a cidade com suas belezas naturais e arquitetônicas, será protagonista das vistas estereoscópicas produzidas no Brasil até o final da década de 1950. Assim, seja por sua fotogenia, ou por sua importância política, a cidade do Rio de Janeiro foi grande aliada da estereoscopia no processo de modernização do olhar dos brasileiros.

Buscamos com este artigo trazer a produção estereoscópica brasileira para o centro dos debates acerca da história fotográfica e da cultura visual do país, entendendo a estereoscopia estruturante de um tipo de experiência visual específica. Geralmente deixada em segundo plano nos manuais sobre fotografia e nas pesquisas historiográficas sobre o tema, não se trata de entender a estereoscopia como mais um tipo de fotografia, mas sim como uma técnica com estatuto próprio, que teve um papel relevante na educação visual dos brasileiros. Mais do que uma ruptura radical da figura do observador, acreditamos que a "mirada estereoscópica" é parte de um todo de novidades que a modernidade do século XIX trazia para o mundo. Como afirmou Hans Ulrich Gumbrecht, "cada novo médium transforma a mentalidade coletiva, imprimindo-se no relacionamento das pessoas com seus corpos, consciência e ações". ${ }^{74}$

\footnotetext{
73 PARENTE, José Inácio. A Estereoscopia no Brasil. Op. cit., p. 75.

74 GUMBRECHT, Hans Ulrich. The body versus the printing press: media in the early modern period, mentalities on the regin of Castilleand another history of mentalities forms. Poetics, v. 14, n. 3-4, 209227, August 1985. Apud: SUSSEKIND, Flora. Cinematógrafo de Letras... Op. cit. p. 26.
} 


\section{Referências}

\section{Fontes}

\section{Obras de Referência}

George Leuzinger. (Verbete). In: Enciclopédia Itaú Cultural de Arte e Cultura Brasileiras. São Paulo: Itaú Cultural, 2020. Disponível em: http://enciclopedia.itaucultural.org.br/pessoa21629/george-leuzinger. Acesso em: 05 jan. 2018.

Revert Henrique Klumb. (Verbete). In: Enciclopédia Itaú Cultural de Arte e Cultura Brasileiras. São Paulo: Itaú Cultural, 2020. Disponível em: http://enciclopedia.itaucultural.org.br/pessoa21647/revert-henrique-klumb. Acesso em: 05 jan. 2018.

\section{Material Fonográfico}

MUSEU da Imagem e do Som. Fonoteca. LACERDA, C. A redenção da cidade. Discurso de inauguração do MIS, 3 de setembro de 1965.

\section{Imagens e Acervos Fotográficos}

Mascher Stereo Daguerreotype Viewer with Original Image Pair, c.1853. [s.d.]. Collectors Weekly. (Site). Disponível em: https://www.collectorsweekly.com/stories/178056-mascherstereo-daguerreotype-viewer-with. Acesso em: nov. 2019.

ARQUIVO Nacional - Rio de Janeiro. Fundo Fotografias Avulsas. Referência: BR RJANRIO.02.0.FOT.444/445/446.

ARQUIVO Nacional - Rio de Janeiro. Fundo Fotografias Avulsas. RODRIGUES \& Co. Central do Brasil. [1890-1910].

BIBLIOTECA Nacional - Rio de Janeiro. Coleção Thereza Christina Maria, KLUMB Revert Henrique, 1855-1880. fl. 1-76.

BIBLIOTECA Nacional - Rio de Janeiro. KLUMB, R. H. Passeio Público. 1862.

Biblioteca Nacional Digital. (Portal Eletrônico). Colleção D. Thereza Christina, George Leuzinger, Rio de Janeiro entre 1865 e 1874. Disponível em: http://bndigital.bn.br/terezacristina/page3.htm. Acesso em: jan. 2018.

INSTITUTO Moreira Sales - Rio de Janeiro. Veneza, Verascope Richard. [s./d.].

MUSEU da Imagem e do Som. Coleção Guilherme Santos, Série "Retiro Saudoso, 1921". Referência: GSEP:4665- 4775.

MUSEU da Imagem e do Som. Coleção Guilherme Santos. SANTOS, Guilherme. Centenário da Independência do Brasil. 1922.

MUSEU da Imagem e do Som. Coleção Guilherme Santos. SANTOS, Guilherme. Retiro Saudoso. 1921.

MUSEU Imperial. Coleção Sanson. CASTRO, Octávio Mendes de. Palácio Monroe. 1922.

\section{Matérias de Sites, Jornais e Revistas Online}

Coleção de fotografias do Museu Imperial é reconhecida como patrimônio nacional. Museu Imperial. (Site). Publicado em: 2 dez. 2013. Disponível em: 
http://museuimperial.museus.gov.br/imprensa/sala-de-imprensa/4907-colecao-de-fotografiasdo-museu-imperial-e-reconhecida-como-patrimonio-nacional.html. Acesso em: 23 jul. 2018.

No primeiro dia da primavera, as cores de Marc Ferrez (1843-1923). Brasiliana Fotográfica. (Portal Eletrônico). Disponível em: http://brasilianafotografica.bn.br/?p=9714. Acesso em: 30 abr. 2020.

\section{Periódicos}

Boletim de Belas Artes, Rio de Janeiro, n. 9, set. 1945.

Boletim de Belas Artes, Rio de Janeiro, n. 18, jun. 1946, p. 167-168.

Revista A Noite, Rio de Janeiro, $1^{\circ}$ ago. 1950, p. 20.

Revista A Noite, Rio de Janeiro, 1 ago. 1950, p. 20.

O Globo, Rio de Janeiro, 7 jan. 1964, p. 5.

\section{Bibliografia}

ADAMS, Gavin. A mirada estereoscópica e a sua expressão no Brasil. 2004. Tese (Doutorado em Comunicação e Estética do Audiovisual) - Escola de Comunicações e Artes da Universidade de São Paulo, São Paulo.

BENCHIMOL, Jayme Larry. Pereira Passos, um Haussman Tropical. Rio de Janeiro: Biblioteca Carioca, 1992.

CHIAVARI, Maria Pace. O mar, ícone e indício na fotografia pública do Rio de Janeiro (19061922). In: MAUAD, Ana Maria (org.). Fotograficamente Rio: A cidade e seus temas. Rio de Janeiro: FAPERJ, 2016.

COSTA, Helouise; RODRIGUES, Renato. A fotografia moderna no Brasil. São Paulo: Cosac \& Naify, 2004.

CRARY, Jonathan. Técnicas do observador: Visão e modernidade no século XIX. Rio de Janeiro: Contraponto, 2012.

DARRAH, W. C. The world of Stereographs. Nashiville: Land Yatch Press, 1997.

George Leuzinger. (Verbete). In: Enciclopédia Itaú Cultural de Arte e Cultura Brasileiras. São Paulo: Itaú Cultural, 2020. Disponível em: http://enciclopedia.itaucultural.org.br/pessoa21629/george-leuzinger. Acesso em: 05 jan. 2018.

KOSSOY, Boris. Origens e expansão da fotografia no Brasil - século XIX. Rio de Janeiro: FUNARTE, 1980.

MAUAD, Ana Maria; LOPES, Marcos Felipe de Brum. História e Fotografia. In: CARDOSO, Ciro Flamarion; VAINFAS, Ronaldo (orgs.). Novos Domínios da História. Rio de Janeiro: Elsevier, 2012.

MAUAD, Ana. Imagem e autoimagem do Segundo Reinado. In: NOVAIS, Fernando A. (coord.). História da vida privada no Brasil. Vol. 2: Império: a corte e a modernidade nacional. Org.: Luiz Felipe de Alencastro. São Paulo: Companhia das Letras, 1997.

MELLO, M. Teresa B. de. Arte e fotografia: O Movimento Pictorialista no Brasil. Rio de Janeiro: Funarte, 1998.

MESQUITA, Claudia. Um museu para a Guanabara. Carlos Lacerda e a criação do Museu da Imagem e do Som (1960-1965). Rio de Janeiro: Folha Seca, 2009.

PARENTE, José Luiz. A estereoscopia no Brasil. Rio de Janeiro: Sextante, 1999. 
PEIXOTO, Rodrigo. Uma certa imagem de um mundo: Estereoscopia e educação visual no início do século XX; uma investigação a partir da coleção Pestalozzi (MIMO). RCL - Revista de Comunicação e Linguagens, Lisboa, n. 47, p. 34-52, 2017.

PEREIRA, Adriana M. P. Martins. A cultura amadora na virada do século XIX: A fotografia de Alberto Sampaio (Petrópolis/Rio de Janeiro, 1888-1914). 2010. Tese (Doutorado em História Social) Faculdade de Filosofia, Letras e Ciências Humanas da Universidade de São Paulo, São Paulo.

PESSANHA, Maria Edith de Araújo. A Estereoscopia: O Mundo em Terceira Dimensão. Rio de Janeiro: M. E. A. Pessanha, 1991.

Revert Henrique Klumb. (Verbete). In: Enciclopédia Itaú Cultural de Arte e Cultura Brasileiras. São Paulo: Itaú Cultural, 2020. Disponível em: http://enciclopedia.itaucultural.org.br/pessoa21647/revert-henrique-klumb. Acesso em: 05 jan. 2018.

SANTOS, Ma. Isabela M. dos. A mirada estereoscópica de Guilherme Santos: Cultura Visual na cidade do Rio de Janeiro Séculos XIX e XX. 2019. Tese (Doutorado em História) - Instituto de História da Universidade Federal Fluminense, Niterói (RJ).

SANTOS, Ma. Isabela M. dos. Cenas Cariocas. O Rio de Janeiro através das estereoscopias de Guilherme Santos (1910-1957). 2014. Dissertação (Mestrado em História) - Instituto de Ciências Humanas e Filosofia da Universidade Federal Fluminense, Niterói (RJ).

SCHWARCZ, Lilia Moritz. As Barbas do Imperador: D. Pedro II, um monarca nos trópicos. São Paulo: Companhia das Letras, 1998.

SILVA, Ma. Cristina Miranda da. A presença dos aparelhos e dispositivos ópticos no Rio de Janeiro do século XIX. 2006. Tese (Doutorado em Comunicação) - Pontifícia Universidade Católica de São Paulo, São Paulo.

SUSSEKIND, Flora. Cinematógrafo de Letras. Literatura, técnica e modernização no Brasil. São Paulo: Companhia das Letras, 1987.

TURAZZI, Maria Inez. Marc Ferrez: Fotografias de um "artista ilustrado". São Paulo: Cosac \& Naify, 2000.

TURAZZI, Maria Inez. Poses e Trejeitos: a fotografia e as exposições na era do espetáculo. Rio de Janeiro: Funarte; Rocco, 1995.

VASQUEZ, Pedro Karp. Revert Henrique Klumb: um alemão na Corte Imperial brasileira. Rio de Janeiro: Capivara, 2001. 